\title{
Archeologie ve službách národní emancipace - dva př́klady z Bosny a Hercegoviny a Chorvatska
}

\author{
Archaeology in the service of national emancipation - \\ two examples from Bosnia and Herzegovina and Croatia
}

\section{Soňa Dvořáčková}

\begin{abstract}
Abstrakt
Archeologie je vědním oborem, který je nucen pohotově reagovat na aktuální společenské klima. Archeolog sám je produktem své doby a není tak schopen aktuální společenský diskurz zcela pominout. Z minulosti navíc existuje dostatek př́kladů, kdy badatelé své poznatky museli upravovat podle konkrétního politického zadání. Archeologie tak často sloužila k obhajování různých nacionalistických nároků, především těch územních. Předložený článek je případovou studií z jihoslovanského prostoru. Na přikladech tzv. bosenských pyramid a raně středověkých chorvatských pohřebišt' ukazuji, že archeologie je $v$ podmínkách nestabilní společensko-politické situace pro národní požadavky využitelná i v dnešní době.
\end{abstract}

\section{Klíčová slova}

Archeologie, nacionalismus, společnost, Balkán, Bosna a Hercegovina, Chorvatsko

\begin{abstract}
Archaeology is a discipline which has to promptly react to the current social climate. An archaeologist himself is a product of his time and is thus not able to completely disregard the current social discourse. Moreover, we know examples from the past where the researchers had to modify their knowledge according to specific political assignments. Archaeology thus often served to advocate various nationalistic requirements, above all the territorial claims. The presented article is a case study from the southern Slavic area. The examples of the so-called Bosnian pyramids and early medieval Croatian cemeteries demonstrate that in an unstable social-political situation, archaeology can be used also today for national claims.
\end{abstract}

\section{Key words}

archaeology, nationalism, society, Balkan Peninsula, Bosnia and Herzegovina, Croatia 


\section{1. Úvod}

Archeologie patř́i mezi vědní disciplíny, které snadno podléhají trendům celospolečenského diskurzu. Samotní badatelé více či méně vědomě přizpůsobují interpretace archeologických pramenů aktuálnímu společenskému klimatu a do svých prací promítají své vlastní politické názory a životní postoje. A nejen to. $\mathrm{Z}$ minulosti máme více než dostatek příkladů, že archeologie své poznatky musela upravovat podle konkrétního politického zadání. Stačí připomenout archeologii nacistického Německa obhajující státní expanzivní politiku či vznik tzv. slovanské archeologie po druhé světové válce. Kromě toho je archeologie vědou, již si rádi přivlastňují nejrůznější senzacechtiví nadšenci.

Archeologie je zneužitelná především v otázkách nároku určitého etnika na určité území. I když by se mohlo zdát, že takové úvahy jsou již minulostí, opak je pravdou. V dnešním světě v souvislosti s uprchlickou krizí opět vyvstávají otázky identit a vlastní národní minulosti. Národ, který se cítí být jakkoliv ohrožen a potřebuje obhájit svou existenci v určitém prosto$\mathrm{ru}$, se obrací právě k archeologii. $\mathrm{V}$ prostoru zemí bývalé Jugoslávie jsou vzhledem k relativně nedávným událostem národní otázky stále živé. U některých národů jihovýchodní Evropy národní emancipace a sebeidentifikace stále pokračuje, a proto je zajímavé podívat se na to, jakou roli v těchto procesech hraje právě archeologie.

Předložený článek vychází z bakalářské práce autorky, obhájené na Katedře jihoslovanských a balkanistických studií FF UK v září 2020 (Dvoráćcková 2020). Práce je případovou studií postavenou na dvou př́kladech. Na jedné straně jde o případ pseudoarcheologie (definice Fagan 2006) v nestabilním mnohonárodnostním státě, na straně druhé o ukázku manipulace s vědeckými poznatky $\mathrm{v}$ prostředí stabilizovaného národního státu, členské země Evropské unie.
Článek analyzuje způsob komunikace projektu „Bosenských pyramid Slunce“ Semira Osmanagiće s veřejností, ukazuje, jakým způsobem je nakládáno s fakty, a jak jsou takto upravené „poznatky“ servírovány nejen domácí, především bosňácké, veřejnosti, ale i veřejnosti zahraniční. Studie se snaží postihnout, jakým způsobem jsou v této souvislosti prezentovány bosňácké národní myšlenky. Druhý příklad naopak spadá do akademické sféry. Na příkladu studia raně středověkých „chorvatských“ pohřebišt’ ukazuji, jakým způsobem renomovaní badatelé upravují fakta tak, aby vyhovovala jejich pojetí dějin.

\section{Národ a nacionalismus}

Úvodem je potřeba definovat pojmy národ a nacionalismus. Podle A. Gellnera je „nacionalismus pưvodně politický princip, který tvrdi, že politická a národni jednotka musí být shodné. Národnostni citèni je pocit hněvu způsobený porušováním tohoto principu, nebo pocit uspokojeni zpisobený jeho splněnim. Národnostni hnuti je hnutí, které je uváděno do pohybu takovým citem " (Gellner 1993, 12). Mezi badateli nicméně existuje mnoho názorových skupin na problematiku vzniku národa a jeho definice. Jde zejména o postoj vůči faktoru minulosti národa. Jsou badatelé, kteří považují národy za kompletní vynález 19. století, za konstrukt moderní společnosti. Na druhé straně pak stojí badatelé, kteří kladou důraz na kontinuitu se staršími státními útvary, na plynulý vývoj státu a „národa“ de facto od středověku (Hroch 2009, 40-43).

Moderní národy se nicméně utvářejí v průběhu 19. století v souvislosti s hlubokými společenskými proměnami, industrializací, s mobilitou obyvatel a jejich stěhováním do měst, přetrháváním tradičních vazeb, celoplošným přístupem k základnímu vzdělání, a tudíž gramotností, a rovným přístupem ke kultuře. Vy- 
tváří se jednotná masa lidí se společnou identitou a vědomím pospolitosti napřríc sociálními třídami (Eriksen 2012, 169).

Utváření národa a nacionalistické ideologie však probíhalo různými zpơsoby $\mathrm{v}$ závislosti na konkrétních podmínkách a okolnostech, $\mathrm{v}$ nichž se národ formoval. Badatelé se s různou úspěšností snažili na základě těchto znaků nacionalismy klasifikovat. V roce 1945 přišel americký politolog Hans Kohn s členěním nacionalismu na západní a východní. Podle Kohna se západní nacionalismus označuje někdy také jako francouzský a opírá se především o stát, jeho teritorium a občany. Východní nacionalismus, označovaný též jako německý, staví naopak na etnokulturním základě, na myšlence společného původu a národní minulosti (Hroch 2003; Prtina 2005).

Pro utváření mnohých národů byla klíčová otázka poznávání národní minulosti. Koncepce národních dějin měla význam pro národní sebevědomí, nebot historické vědomí posilovalo identitu s národem, dějiny legitimizovaly národní existenci (Hroch 2009, 177-178). Vědecká konstrukce národních dějin však mohla plnit své poslání jen tehdy, pokud nalezla cestu do historického vědomí publika, k němuž se obracela národní agitace (Hroch 2009, 189). Veřejnost a mecenáši se začali mnohem více zajímat o kulturní památky a jejich výpověd’, začala „znovuvýstavba“ hradů, byly zakládány spolky na ochranu památek (Thiessová 2007, 126-127).

Čím starší počátky mohl národ doložit, tím vyšší byla jeho prestiž a tím větší váhu měly jeho nároky. Nevládnoucí etnika pak obvykle měla potřebu dokázat, že existovala už v hluboké minulosti (Hroch 2009, 174). Mnohé národy měly představu o svém zlatém věku, $\mathrm{k}$ němuž se vzhlíží a který byl vzorem pro současnost (Hroch 2009, 77). Zlatý věk národa a mýtus národního původu pak bylo možno od 19. století hledat prostřednictvím archeologie a prvních vykopávek. Historii národa díky archeologii bylo mož- no protáhnout do období prehistorického, tedy do období, kdy minulost není možno rekonstruovat na základě písemných pramenů (např̀ Hroch 2009, 193). Vznikla tedy poptávka po památkách minulosti, kterou byla schopna uspokojit jedině archeologie. Emancipace archeologie jako samostatného vědního oboru tak šla ruku v ruce $\mathrm{s}$ formováním národů a vznikem nacionalismu.

Norský kulturní antropolog T. H. Eriksen říká: „Obecně se dá ř́ci, že sociálni identita se stává nejdůležitější ve chvili, kdy se zdá být ohrožena“" (Eriksen 2012, 118). Nacionalismus se proto nejsilněji projevuje v období změn, kdy je třeba ukázat „těm druhým“ kdo jsme a čím se odlišujeme. Národ, který se cítí být ohrožen, začne prezentovat svou národní minulost a mýty a dokládat, že na území žije „od nepaměti“. Situace v některých zemích bývalé Jugoslávie stále není zcela stabilizovaná. Vzpomínky na krvavý rozpad země a nacionalisticky motivované válečné zločiny stále zcela nevymizely a národní otázky tak jsou stále aktuální.

\section{Archeologie a nacionalismus}

Studium etnicity patří k tématům, která v posledních letech v archeologii velmi silně rezonují. Možnost či nemožnost poznání etnicity minulých populací patří k otázkám, které vzbuzují přirozenou pozornost badatelů. Stačí si vzpomenout na četné práce z pera německých archeologů Waltra Pohla (např. Pohl 2010) a Sebastiana Brathera (např. Brather 2000), českých archeologů Petra Květiny (Květina 2010) či Ivo Štefana (např. Štefan 2011), z chorvatského prostředí pak zejména práce Gorana Bilogriviće (Bilogrivić 2016). Před zhruba desetiletím rozvířila vody (nejen) české archeologie diskuse kolem článku amerického badatele rumunského původu Florina Curty ohledně skutečné či smyšlené slavinity archeologických nálezů raného 
středověku střední, východní a jihovýchodní Evropy (viz Curta 2008, Profantová 2009, Biermann 2009, Pleterski 2009 a 2013).

Tématem mé studie však není otázka možnosti či nemožnosti poznání etnicity minulých populací, o čemž polemizují výše zmíněné práce, nýbrž pohled zcela opačný - tedy jakým způsobem se archeologie podílí na národním cítění či nacionalismu, jak je využívána ke konstruování „slavné národní minulosti“ a jakou roli hraje $\mathrm{v}$ šíření národního povědomí mezi širší veřejností.

Jedním z rysů nacionalismu je tendence opírat národní cítění o slavnou minulost národa a teritoria, na němž národ žije. Slavná minulost tak má pro národní emancipaci klíčový vliv, a pokud se nedostává písemných pramenů a mytologie, které by ideu slavné minulosti podpořily, dostává se ke slovu archeologie. Ta totiž může počátky národa „protáhnout“ více do minulosti, do doby před vynalezením písma.

Aby vyjádření etnicity bylo účinnější, vyžaduje zakotvení v určitém geografickém prostředí. A jak říká M. Dietler, „... archeologie toto zakotveni zajištuje tím, že váže dohromady místa s dávnými událostmi a lidmi“(Dietler 1999, 551). Ve středoevropském prostoru byly v relativně nedávné minulosti klíčové především otázky vymezení teritoria, na které má ten či onen národ přirozený nárok, protože jeho lid prostor obýval „od nepaměti“. Notoricky známým prŕkladem je zneužití teorie německého archeologa Kossiny nacistickým Německem (k archeologii v nacistickém Německu více např. Arnold 1990).

Naopak po válce vznikla potřeba dokázat, že naše země byly obývány Slovany dříve než Němci. Vznikla tzv. „slovanská archeologie“, která se věnovala raně středověkému období, zdůrazňoval se společný slovanský původ Čechů a Slováků a hledaly se „odvěké“ vazby k Rusku (Turek 2019, 209). Se státní podporou (Brather 2001) začaly rozsáhlé výzkumy „slovanských“ hradišt a pohřebišt. Terénní projekty „režim vital, ne- bot’ mohly posloužit $k$ prezentaci úspěchů nového politického zřizeni a ilustrovat základni linii nové interpretace dějin " (Kuna - Starcová - Mařrková-Kubková a kol. 2019, 101).

Každá práce vzniká v kontextu určité doby a archeologie jako společenskovědní obor reaguje na aktuální celospolečenskou poptávku. M. Dietler píše: „... archeologové sami jsou produkty konkrétního sociohistorického kontextu a jejich interpretace a hodnoceni věrohodnosti nejsou na tomto kontextu nezávislá" (Dietler 1999, 552). Archeo$\log$ do svých interpretací at’ už vědomě nebo nevědomě vkládá část svých osobních postojů a náhledů na svět. I tak se může nacionalismus vkrádat do jinak odborných děl. Kromě toho archeologové své interpretace zasazují do již existujícího historického konstruktu, který v zásadě vznikal v nacionalistickém devatenáctém století. Archeologie se stává součástí výkladu národnich dějin.

\section{Národnostní složení ve studovaném regionu}

Studovaný areál je charakteristický složitou národnostní situací, jejíž kořeny je nutno hledat již v období nadvlády Osmanské říše. Jedním z důvodů etnické rozdrobenosti prostoru jsou přesuny obyvatelstva. Osmanské úřady ve snaze zabránit vzpourám cíleně přesouvaly skupiny obyvatelstva a uvolněná území kolonizovaly tureckým obyvatelstvem. Další přesuny obyvatelstva přinesly rakousko-turecké války. Politické dějiny prostoru tak výrazným způsobem pozměnily etnickou skladbu obyvatelstva Balkánu (Rychlik 2020).

Oproti středoevropskému a západoevropskému prostředí, kde při vzniku národů měl hlavní úlohu sdílený jazyk, hrálo v jihovýchodní Evropě při vzniku národního vědomí důležitou roli náboženství. Kořeny etnické identifikace na základě náboženství je možno hledat opět 
v Osmanské říši. Tento multietnický stát klasifikoval obyvatelstvo jediným způsobem, a to podle náboženství; po roce 1453 bylo obyvatelstvo osmanské ř́šse členěno do tzv. milétů (Budilová 2012, 20-25). Ostatní znaky, jako etnicita, jazyk, pokrevní vztahy a kultura nehrály v klasifikaci obyvatelstva žádnou roli (Budilová 2012; Rychlik 2020).

Během 19. století se pod vlivem západních myšlenek na náboženství založená identita zvolna transformovala do identity sekulární a začala stavět národní vědomí i na faktorech jako je jazyk či sdílená historie. Zatímco v multietnické Osmanské říši žila etnika vedle sebe v relativně klidné koexistenci, problémy se vyhrotily ve chvíli, kdy došlo k zformování moderních národů a začal proces národně osvobozeneckého boje, v němž už hrál stěžejní roli západní nacionalismus. Během vytyčování hranic nově vznikajících národních států docházelo opět $\mathrm{k}$ rozsáhlým přesunům nežádoucího obyvatelstva, především Turků (Rychlik 2020; Šistek 2017, 98-99).

První světová válka změnila politickou mapu Evropy. Rozpadly se multietnické monarchie a prosadil se model národnostních států. Srbové, Chorvaté i Slovinci už v té době představovali moderní národy, okolnostmi však byli nuceni přijmout ideu jednoho jihoslovanského (jugoslávského) národa o třech větvích. Vznik Království SHS na konci roku 1918 nebyl žádným vyvrcholením přirozeného vývoje, ale ryze účelovým útvarem, jehož vznik byl podmíněn dobovými okolnostmi (Šesták a kol. 2001, 380-383).

Socialistická Jugoslávie postavila svou ideologii na hesle „bratrství a jednoty“2 vycházející z idey etnické př́ibuznosti státotvorných slovanských národů, přičemž do tohoto „bratrství“ byly zahrnuty i početné neslovanské jugoslávské menšiny (Štěpánek 2012, 40). Kromě národních identit byla $\mathrm{k}$ dispozici zastřešující jugoslávská identita, k níž se hlásili především jedinci ze smíšených manželství a zejména obyvatelé velkých měst (Žila 2013). Národy měly v toleranci, bratrství a jednotě žít vedle sebe a každý národ měl právo na svůj vlastní kulturní rozvoj. Dohlíželo se na rovnoprávnost jednotlivých národů a jejich rovnoměrné zastoupení v řízení státu. Nacionalismus byl považován za nebezpečnou ideologii a byl programově potírán (Štěpánek 2012).

Jugoslávská ústava z roku 1974 oficiálně přiznala status národa také Muslimům³ ${ }^{3}$ kteří byli zpočátku považováni pouze za specifickou náboženskou skupinu (Žila 2016, 73). Ústava však nechtěně přispěla $\mathrm{k}$ rozklížení republiky a její postupné konfederalizaci. Většinu pravomocí totiž přenesla do rukou republikových vlád a oslabila tak pozici federálních struktur. Republiky čím dál tím více sledovaly své vlastní zájmy a ústava tak nepřímo přispěla $\mathrm{k}$ rozvoji nacionalismu v jugoslávských republikách (Žila 2019, 69).

Po smrti Josipa Broze Tita (1980) pak již nebyla síla, která by dokázala rozklíženou Jugoslávii držet pohromadě. Ke slovu se víc a víc hlásil nacionalismus, v podstatě jako jediná alternativa ke komunismu (Štěpánek 2012). Na povrch se dostaly staré křivdy, po celou dobu trvání Jugoslávie držené pod pokličkou, o nichž se nesmělo veřejně mluvit, ale $\mathrm{v}$ rodinách se o nich vyprávělo a vědělo (Prtina 2005). Nepotrestané a neodsouzené zločiny z druhé světové války se tak stávaly záminkou pro národní agitaci u širokých mas.

První demokratické volby ve svazových republikách na plné čáře vyhrávaly právě nacionalistické strany. Volební program občansky orientovaných stran oproti jednoduché a srozumitelné rétorice nacionalistů nebyl schopen voliče zaujmout a tyto strany neměly ve volbách sebemenší šanci (Prtina 2005, 33). Nacionalismus se stal jedním z faktorů, které rozpoutaly válku v Jugoslávii v první polovině devadesátých let dvacátého století (více Štěpánek 2012). Napětí 
mezi jednotlivými republikami i etniky vyvrcholilo krvavým rozpadem Jugoslávie. Bylo zjevné, že osamostatňování jednotlivých republik podporuje jen většinové obyvatelstvo. Menšina zpravidla chtěla setrvat v původním mnohonárodním státu a odmítala být součástí nového národního státu, kde by měla menšinové postavení a stala by se občany druhé kategorie. Proto vznik nových států doprovázely pokusy se tohoto nepohodlného obyvatelstva zbavit a během válečných konfliktů došlo na všech stranách k etnickým čistkám (Rychlik 2020).

Daytonská smlouva, sjednaná na americké vojenské základně nedaleko města Dayton a podepsaná 14. 12. 1995 v Paříži, ukončila válku v Bosně a Hercegovině, ale neodstranila příčiny, kvůli nimž k válce došlo (Žila 2016; Žíla 2018, 9). Formálně jednotná Bosna a Hercegovina byla rozdělena smlouvou do tří entit: mezi Federaci Bosny a Hercegoviny (51 \% území), Republiku srbskou (49 \%) a Distrikt Brčko, spravovaný společně všemi třemi konstitutivními národy. Entity disponují velkou mírou autonomie s vlastními státními složkami, včetně policie.

Podle nejnovějšího sčítání lidu z roku $2013^{4}$ žije v Bosně a Hercegovině víc jak 3,5 milionu obyvatel, z toho 50,11 \% Bosňáků, 30,78 \% Srbů a 15,43 \% Chorvatů. Ze sčítání lidu je zřejmé, že i dnes je v Bosně a Hercegovině příslušnost k národnosti a náboženství považována za klíčovou a etnická identifikace jednotlivce hraje stále velkou roli (Žarković 2014). Obyvatelstvo se hlásí k jedné ze tří národností a zastřešující, bosenská, identita $\mathrm{v}$ podstatě chybí. Jednotnou identitu země se snaží prosadit jediný národ- Bosňáci (Muslimové), pro než je Bosna a Hercegovina na rozdíl od Srbů a Chorvatů mateřským státem. Bosňácký nacionalismus je skrytý a jejich unitarizační snahy jsou z hlediska západního pozorovatele logické a ospravedlnitelné, na rozdíl od decentralizačních snah bosenských Srbů a Chorvatů (Žila 2018; Žila 2016, 117; Mujanović 2014).
Země se také potýká s velkou mírou nezaměstnanosti ${ }^{5}$, odchodem pracovníků za lepšími výdělky do zahraničí, v př́ípadě Srbů a Chorvatů odchodem mladé generace do mateřských republik. ${ }^{6} \mathrm{~V}$ takové situaci je logické, že ekonomickou situací frustrovaní lidé vítají jakoukoliv možnost zlepšit svou finanční situaci.

Poněkud odlišná je situace v Chorvatsku, které je nyní etnicky homogenním státem a procento menšin je nepatrné. $V$ době socialistické Jugoslávie měli Srbové v Chorvatsku status konstitutivního národa. To se změnilo v roce 1990 přijetím nové republikové ústavy, která Chorvatsko nově definovala jako stát Chorvatů a národnostních menšin (Rychlik 2016, 236). S novou formulací Srbové nesouhlasili, Chorvaté však jejich návrhy na změnu nepřijali, čímž napětí mezi oběma etniky dále eskalovalo. Celý spor vyvrcholil vyhlášením Republiky srbská krajina a občanskou válkou. Operace Blesk a Bouře v roce 1995 způsobila odchod několika tisíc Srbů z Chorvatska, které se tak stalo národním státem jediného národa a menšiny v jeho chodu hrají minimální roli. Podle nejnovějšího sčítání lidu z roku 2011 žije v Chorvatsku asi 4,3 milionu obyvatel. Drtivou většinu tvoří Chorvaté $(90,42 \%)$, největší menšinou jsou Srbové (4,36 \%), zbylá etnika nedosáhla ani hranice $1 \%{ }^{7}$

Na rozdíl od sousední Bosny a Hercegoviny je situace v Chorvatsku relativně stabilizovaná. Chorvatsko je součástí mezinárodních politických a bezpečnostních struktur, 1. dubna 2009 vstoupilo do NATO, 1. července 2013 do Evropské unie. Národnostní menšiny mají ústavně zakotvená práva na národnostní rozvoj a právo na národní zastoupené v saboru. Z hlediska mezinárodních vztahů působí Chorvatsko jako stabilizační prvek západního Balkánu (Rychlik 2016). Navzdory tomu se ale stále častěji mluví o vzrůstajícím nacionalismu, nenávisti vưči menšinám a využívání ustašovských symbolů na veřejnosti. ${ }^{8}$ Operaci Bouře připomíná státní svátek 
(5. 8.) a tato válečná operace spojená s násilným odsunem mnoha tisíc Srbů je oslavována jako den vítězství. ${ }^{9}$ Značný úspěch též v posledních letech slaví krajně pravicové strany. ${ }^{10}$

\section{Bosenské „Pyramidy Slunce”}

V dubnu 2005 dorazil do Visoka na pozvání ředitele místního muzea Senada Hodoviće americký podnikatel bosenského původu Semir Osmanagić (Pruitt 2007, 17). Během jeho krátkého pobytu jej zaujaly pravidelné tvary kopce Visočica. Osmanagić, který se již dříve věnoval tajemstvím pyramid po celém světě, prohlásil, že dva vrchy v okolí Visoka, Visočica (766 m n. m.) a Plješevica (660 m n. m.) jsou ve skutečnosti nerozpoznané, hlínou a vegetací zanesené pyramidy. Nazval je pyramidami Slunce a Měsíce. ${ }^{11}$

Ještě na podzim roku 2005 vydal Osmanagić svou první monografii věnovanou údajným bosenským pyramidám s názvem „Bosenská pyramida Slunce - objev první evropské pyramidy“ (Osmanagić 2018, 53). Následně vykoupil část pozemků v bezprostředním okolí kopce Visočica (Hammer - Swartz 2020, 95), založil „Nadaci Archeologický park: bosenská pyramida Slunce“ (Fondacija Arheološki park: bosanska piramida Sunca) a s povolením místního muzea začal na jaře 2006 s výzkumnými pracemi (Pruitt 2007, 17). „Objev“ ihned přitáhl pozornost světových médií. $\mathrm{V}$ zimě na přelomu roku 2006 a 2007 pak Osmanagić s objevem podnikl cestu po bosenských velvyslanectvích na celém světě, včetně velkých měst jako je New York či Londýn (Pruitt 2007, 20).

Postupem času objevil Osmanagić v okolí Visoka několik dalších „objektů“- dvě nové pyramidy- Pyramidu Lásky (kopec Cemerac, 654 m n. m.) a Bosenského draka (Bučki Gaj, 570 m n. m.), mohylu/pyramidu zvanou Chrám Matky Země (Krstac, 633 m n. m.), mohylu ve Vratnici a komplex tunelů Ravne.
Odborná veřejnost se k objevu „pyramid“ postavila kriticky. Zamítavě se vyjádřili jak geologové z Katedry přírodních geologických disciplín na univerzitě v Tuzle, kteří byli na podzim 2005 přizváni ke spolupráci (Vrabac a kol. 2006), tak archeologové. Z bosenských archeologů vystoupili proti tezi o existenci pyramid tehdejší kurátorka Zemského muzea v Sarajevu Ziljka Kujundžić-Vejzagić, ${ }^{12}$ Enver Imamovićc ${ }^{13}$ z Filozofické fakulty sarajevské univerzity či Dubravko Lovrenović z Komisije za očuvanje nacionalnih spomenika. ${ }^{14} \mathrm{~K}$ bosenským archeologům se brzy s kritikou připojili jejich zahraniční kolegové, ${ }^{15}$ především Anthony Harding, tehdejší prezident European Association of Archaeologists (Harding 2007). Proti aktivitám Semira Osmanagiće vznikla také petice. ${ }^{16}$

Bosenské pyramidy tak okamžitě po svém „objevení“ vyvolaly vlnu kontroverze. Na jedné straně získaly řadu fanoušků a pozornost médií, na druhou stranu se objevovaly komentáře upozorňující na to, že projekt není ničím jiným než pseudoarcheologií. Proti pyramidám ve Visoku vzniklo několik webových stránek, ${ }^{17}$ dále diplomová práce Tery Pruitt (Pruitt 2007) z univerzity v Cambridge a celá řada dílčích článků zahraniční produkce (Rose 2006; Kampschror 2006 a další).

Bosňáčtí političtí představitelé však vyjádřili projektu podporu (Pruitt 2007, 25). Danijel Džino píse: „Nakonec se (pyramidy) staly užitečným nástrojem používaným bosňáckými politiky a náboženskými vi̊dci pro jejich vlastni propagaci" (Dzino 2012, 184). ${ }^{18}$ Místo navštívil napřriklad Haris Silajdžić ${ }^{19}$ a prohlásil, že objev pyramid má velký význam pro ekonomiku země. Mluví se také o finanční podpoře projektu muslimskými zeměmi (Pruitt 2007, 38), zpočátku zejména Malajsií. ${ }^{20}$ Naopak představitelé bosenských Srbů a Chorvatů se k projektu postavili rezervovaně a žádný z jejich politiků místo nenavštívil (Dzino 2012, 184).

$\mathrm{Na}$ začátku června 2006 hovořil Sulejman Tihić $^{21}$ na summitu v Opatiji s generálním 
ředitelem světové organizace UNESCO Koichiro Matsuurou. V rozhovoru jej informoval o objevu bosenských pyramid a tvrdil, že pyramidy zkoumá tým renomovaných archeologů. Matsuura přislíbil, že do Visoka pošle komisi složenou z odborníků, aby objev potvrdili (Rose a kol. 2006). Zpráva o plánované cestě týmu odborníků s pověřením UNESCA do bosenského Visoka se záhy rozšíríila do světových médií a archeologové reagovali pohotově. Již 12. června sestavili dopis adresovaný př́mo generálnímu řediteli organizace UNESCO Koichiro Matsuurovi. Petice signovaná předními osobnostmi celosvětové, především však americké, archeologie uvádí, že celý projekt není ničím jiným než pseudoarcheologií a že Semir Osmanagić svými aktivitami ohrožuje skutečné archeologické dědictví (Rose a kol. 2006). Na temeni kopce Visočica, tzv. Pyramidy Slunce, se nachází vrcholně středověká pevnost $\mathrm{s}$ přilehlým středověkým městem, které bylo výkopovými pracemi Osmanagiće a jeho týmu ohrožené- výkopy zničily skutečné archeologické situace a vše probíhalo bez adekvátní terénní dokumentace. ${ }^{22}$

V červnu 2007 se na nátlak odborné veřejnosti ministr kultury Gavrilo Grahovac rozhodl odejmout Osmanagićovi povolení k výzkumu. Nadace na to reagovala šedesátistránkovým dopisem, v němž zpochybnila výroky geologů a archeologů a snažila se doložit, že její aktivity nemohou být považovány za pseudovědu. ${ }^{23}$ Také kvưli masivním demonstracím veřejnosti ve Visoku pak bylo povolení Osmanagićovi navráceno (Pruitt 2007, 20-21).

Občané Visoka totiž objev pyramid od samého počátku vítali. ${ }^{24}$ Projekt do města láká turisty z celého světa a ti přirozeně přinášejí peníze. Už v roce 2006 přivítalo Visoko 250000 turistů zvědavých na pyramidy (Pruitt 2007, 39). V letech 2017 a 2018 návštěvnost kolísala kolem 50000 návštěvníků ročně. Narůstající čísla zaznamenaly statistiky evidující ubytovací kapacity i počty nocí, které návštěvníci Visoka ve městě stráví. ${ }^{25}$
Visoko se za patnáct let stalo místem masové turistiky. $Z$ turismu těží lokální podnikatelé nabízející své služby v ubytovacích službách, restaurace i drobné obchůdky se suvenýry. Nadace nabízí vstupy na jednotlivé pyramidy od pěti Euro, přes exkurze různé délky v ceně pohybující se od 13 Euro do 35 Euro až po náročné vícedenní exkurze vedené samotným Semirem Osmanagićem se zajištěným ubytováním v ceně 1000 Euro i více. ${ }^{26} \mathrm{~V}$ parku Ravne 2 se pořádají workshopy i kulturní akce. ${ }^{27}$ Osmanagić ve svých projevech akcentaci turistického ruchu a finanční přínos pro město nijak neskrývá, naopak poukazuje na př́nos turismu pro Visoko a vlastně i pro celou zemi.

Pyramidový projekt Semira Osmanagiće tak žije svým vlastním životem, aniž by na to odborná veřejnost mohla mít nějaký vliv. Projekt má obrovský dosah u veřejnosti a médií. Když lokalitu navštíví veřejně známá osobnost, Osmanagić z toho dokáže vytěžit maximum a návštěvu využije jako další zdroj své reklamy. Stačí připomenout návštěvu srbského tenisty Novaka Đokoviće v červenci 2020, který v rozhovoru konstatoval, že Osmanagić objevil v Bosně památku světového významu, ${ }^{28}$ nebo nedávnou návštěvu chorvatského europoslance Ivana Sinčiće, který prohlásil, že na památku starou desítky tisíc let mají být Bosňané hrdí a přislíbil, že bude o lokalitě vyprávět kolegům europoslancům s cílem získat podporu pro Osmanagićův projekt. ${ }^{29}$

Bosenské pyramidy se rozšrírily i v povědomí české veřejnosti. Do češtiny byla přeložena jedna z Osmanagićových publikací (Osmanagić 2018), do oblasti se organizují zájezdy ${ }^{30}$, pořádají se přednášky a besedy. Česká odborná veřejnost před zhruba třemi lety musela zasáhnout po odvysílání reportáže v pořadu Objektiv, kde byla Pyramida Slunce představena jako nejvyšší pyramida světa. ${ }^{31}$ Česká televize však po kritice video ze svých stránek stáhla a nyní je už nedohledatelné. V českém prostředí se však 


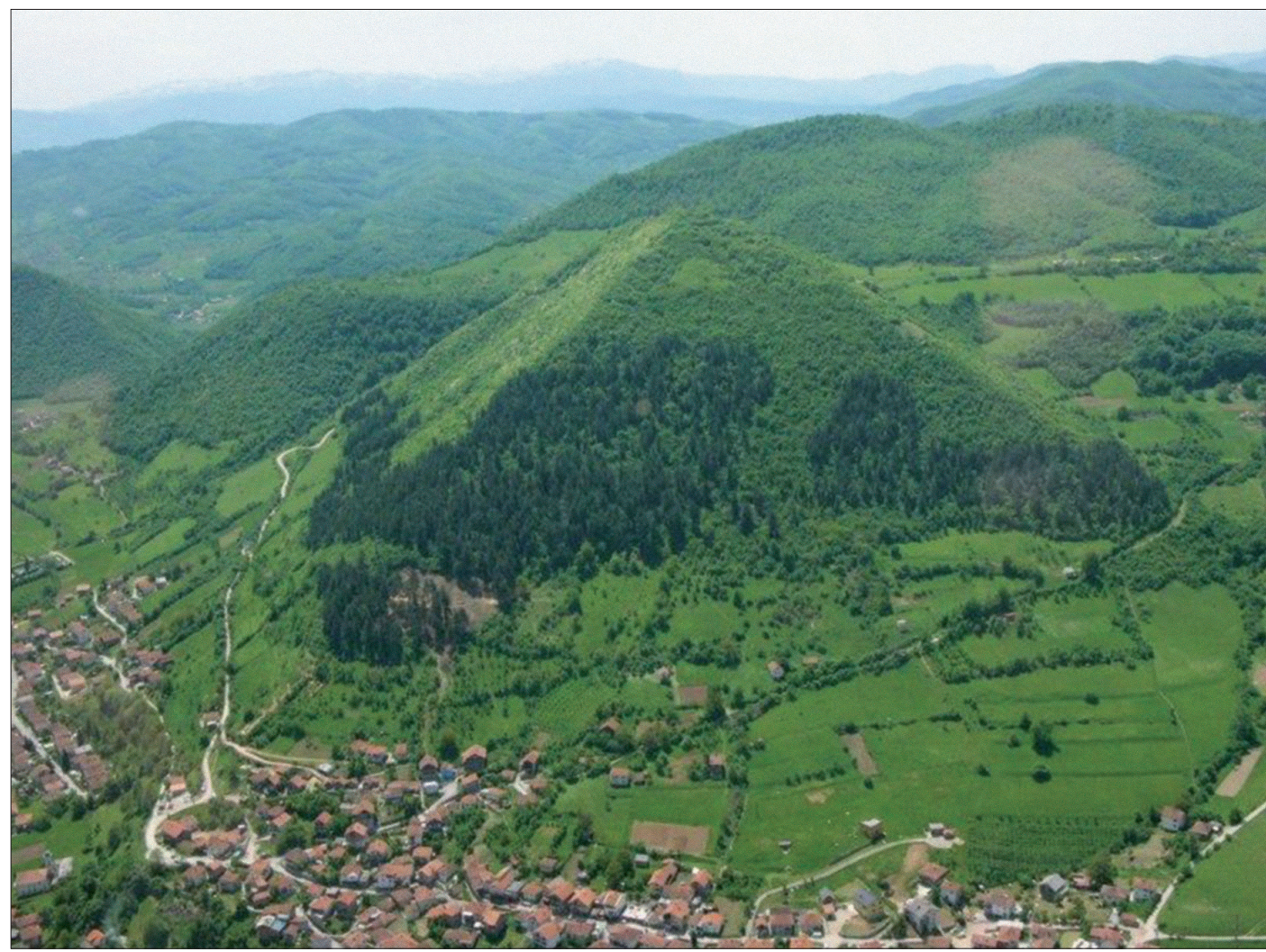

Obr. 1: Kopec Visočica, 766 m n. m., tzv. Pyramida Slunce (Piramida Sunca), zdroj: wikipedia.org: https://bs.wikipedia.org/wiki/Datoteka:Viso\%C4\%8Dica_hill,_Luke_stadium.jpg.

Fig. 1: The hill Visočica, 766 m ASL, so-called Pyramid of the Sun (Piramida Sunca), source: wikipedia.org: https://bs.wikipedia.org/wiki/Datoteka:Viso\%C4\%8Dica_hill,_Luke_stadium.jpg.

povědomí o Pyramidě Slunce jakožto nejvyšší pyramidě světa šírí dál, a to i vcelku seriózními kanály. ${ }^{32} \mathrm{O}$ alternativních informačních portálech $^{33}$ snad ani nemluvě.

Na tomto místě se dostávám $\mathrm{k}$ tomu, co je vlastně obsahem Osmanagićova pyramidového konceptu. Uvedu zde základní teze jeho „teorie“ v aktuální podobě. Všechna níže uvedená tvrzení je možno nalézt jak v do češtiny přeložené monografii (Osmanagić 2018), tak v různých webových zdrojích, jako je YouTube kanál nebo oficiální webové stránky nadace. ${ }^{34}$ Zdůrazňuji, že veškerá níže uvedená tvrzení jsou záměrně uváděna tak, jak s nimi pracuje Semir Osmanagić.
V „Bosenském údolí pyramid“ bylo do dnešních dnů identifikováno pět pyramid (Slunce, Měsíce, Draka, Lásky a Matky Země), mohylový komplex ve Vratnici a podzemní labyrint Ravne $\mathrm{s}$ minimálně čtyřmi vstupy. Vrcholy tří hlavních pyramid (Slunce, Měsíce a Draka) tvoří rovnostranný trojúhelník o délce strany 2180 metrů (Osmanagić 2018, 51).

Bosenská Pyramida Slunce (Obr. 1) je se svými 270 m nejvyšší pyramidou světa (Osmanagić 2018, 45-46). Stěny se skrývají pod nánosem půdy a vegetace, avšak, jak zjistil „,archeologický výzkum“, její plášt tvoří bloky umělého betonu. Tento beton svými vlastnostmi, tvrdostí a nízkou absorpcí vody, zdaleka předčí beton, 
který jsme schopni vyrobit nyní, v 21. století. Bosenská pyramida Slunce má podle bosenského Geodetického ústavu nejpřesnější orientaci k hvězdnému severu na světě, a to s odchylkou 0 stupňů 0 minut a 12 úhlových vteřin $(O s m a-$ nagić 2018, 46).

Pyramida Měsíce je vysoká 190 m, orientovaná $\mathrm{k}$ západu, původně byla stupňovitá a její terasy pokrývá pískovcová dlažba. Její plášt byl intenzivně „zkoumán“ mnoha sondami. Mohyla ve Vratnici je se svými 61 metry též nejvyšší mohylou na světě. Stejně tak sít prehistorických tunelů je samozřejmě nejrozsáhlejší na světě (Osmanagić 2018, 22-24, 46-48). V podzemním labyrintu Ravne jsou umístěny „keramické megality“, z nichž některé jsou pokryty runovými nápisy (Osmanagić 2018, 56-59).

Bosenské pyramidy jsou nejen nejvyšší, ale i nejstarší na světě. Datace se přitom stále posouvá více do minulosti- první Osmanagićovy datace se spokojily se stářím „pouze“ 12000 let, jeho poslední teorie ovšem počítají s výstavbou pyramid dokonce před 32000 lety (Hammer - Swartz 2020). Jako poslední platné datování uvádí Osmanagić stáří 29200 +/- 400 let, a to podle radiokarbonového datování listu, který byl nalezen ve spáře mezi betonovými bloky. ${ }^{35}$

Osmanagić tvrdí, že pyramida funguje jako generátor energie, vysílající do vesmíru paprsek a komunikující se světy v jiných galaxiích, dále mluví o Teslových skalárních polích nad pyramidou či o zdraví prospěšné Schumannově rezonanci (Osmanagić 2018, 79). Pyramidy a tunely mají díky vibracím údajně pozitivní vliv na lidské zdraví. ${ }^{36}$ Místo se tak stalo vyhledávaným cílem nejen turistů zainteresovaných vidět archeologickou lokalitu, ale i osob, které se zde léčí nebo meditují (Hammer - Swartz 2020).

Projekt Semira Osmanagiće je možno označit za úspěšný. Nesouhlas geologů i archeologů s tvrzeními, že kopce v okolí Visoka jsou dílem prastarých civilizací mimozemského původu, bohužel zapadl. Věda nemá prostředky se šíře- ní těchto dezinformací nijak bránit. Na místě je položit si otázku, jak je možné, že projekt postavený na lži, nebo minimálně na omylu, má takový úspěch u celosvětové veřejnosti.

Následující text se proto pokusí ukázat, jakým způsobem Semir Osmanagić komunikuje s veřejností a jak před laiky obhajuje svá tvrzení, že bosenské pyramidy skutečně existují. Zároveň je konzumentům nenásilně podsouvána „národní myšlenka“, at' už formou použité symboliky či formulacemi typu „obyvatelé Bosny a Hercegoviny mají být na co pyšní“.

Na prvním místě je nutné uvést používaná klišé a symboly. Celý projekt stojí a padá s osobou dr. Semira Osmanagiće, výkonného ředitele nadace. Celý projekt je víceméně „one man show". Osmanagić se prezentuje v roli dobrodruha, amatérského archeologa, pátrajícího po senzačních objevech, o nichž běžní smrtelníci neměli ani tušení. Používá k tomu jednoduchou symboliku z oblasti pop kultury- jeho klobouk má připomínat „nejznámějšího archeologa“ a dobrodruha Indiana Jonese. Své oblečení volí tak, aby tomuto image plně odpovídalo- obvykle nosí světlé kapsáče, vysoké kožené boty a rozhalenou košile s vyhrnutými rukávy (Obr. 2).

Jeho image dobrodruha není jediným klišé, které Osmanagić používá. Symbolika je používána tak, aby na první pohled bylo každému zájemci o pyramidy jasné, co mu má lokalita říct. Na logu nadace tak můžeme vidět mayskou pyramidu, pyramidový tvar je používán ve Visoku na každém kroku k upoutání pozornosti návštěvníků, Hammer a Swartz navíc ve svém textu upozorňují i na jednoduchou, avšak funkční symboliku mimozemštanů na ukazatelích (Hammer - Swartz 2020, 106).

Semir Osmanagić s oblibou užívá titul „doktor" a často sám sebe označuje za akademika (např. Osmanagić 2018, 77). Údajně je zahraničním členem Ruské akademie věd, nicméně $\mathrm{M}$. Lomonosov ve svém článku ř́ká, že certifikát údajně zaslaný z akademie a prezentovaný na 


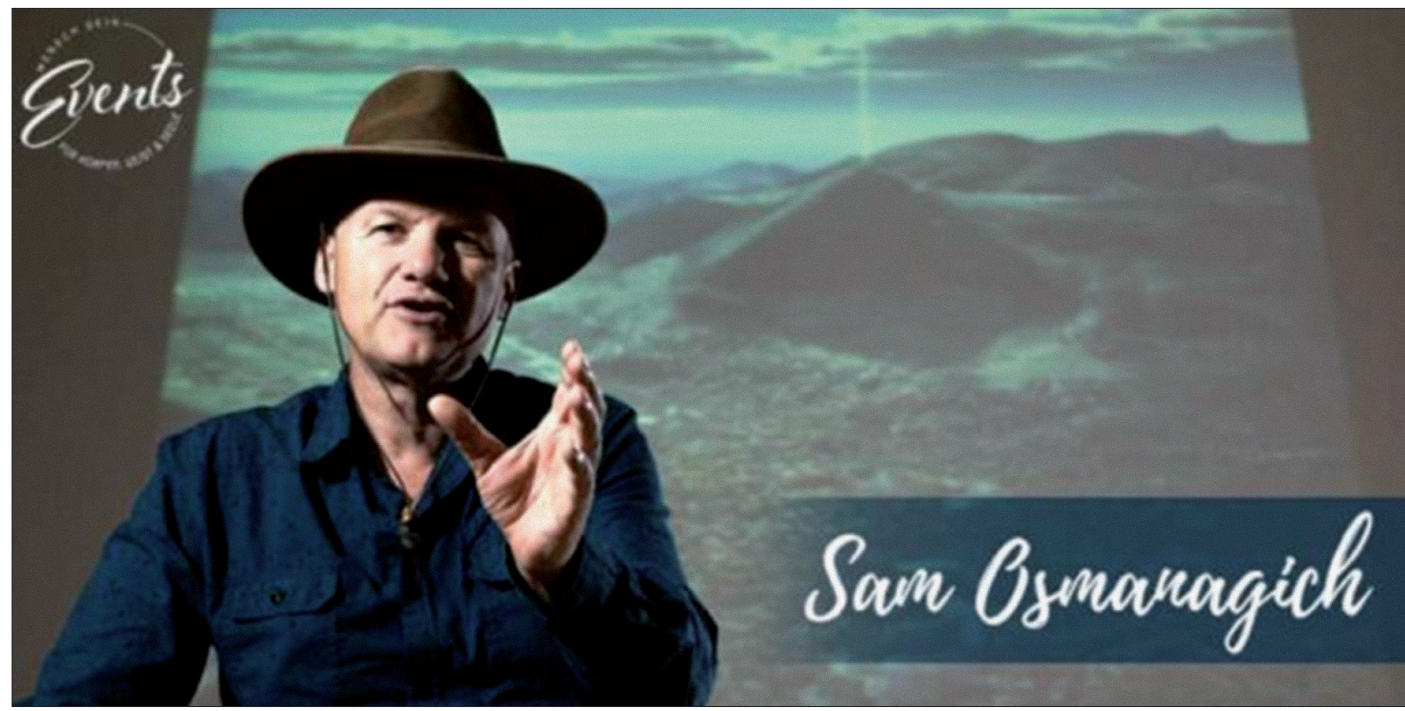

Obr. 2: Semir "Sam” Osmanagić, zdroj: facebookový profil Semira Osmanagiće https://www.facebook.com/ DrSemirOsmanagich.

Fig. 2: Semir Osmanagić, source: http://piramidasunca.ba/bs/

Osmanagićově webu ${ }^{37}$ nese známky padělání (Lomonosov 2012, 80). Jeho osobě akademické tituly zajisté dodávají punc odbornosti, erudovanosti a zvyšuje to $\mathrm{v}$ očích veřejnosti jeho kredit. Semir Osmanagić však nemá titul Ph.D. z oboru archeologie, jak by se na první pohled třeba mohlo zdát. Osmanagić titul získal v roce 2010 za doktorskou disertační práci věnovanou Mayské kultuře, a sice na Fakultě politických věd univerzity v Sarajevu (Džino 2014, 248; Pruitt 2012, 31-32). Osmanagićova disertační práce není ničím jiným než rozšířením jeho dříve vydané alternativní knihy „The World of the Maya“, kterou musel doplnit o sociologickou literaturu, aby vůbec odpovídala standardům vědecké práce (Normark 2012). Navzdory tomu Osmanagić od roku 2011 učí na soukromé American University in Sarajevo, což opět zvyšuje jeho osobní prestiž a budí dojem na slovo vzatého odborníka (Pruitt 2012, 31-32).

Aktivity Osmanagićova týmu budí na první pohled dojem skutečné odbornosti. Semir Osmanagić klade ohromný důraz na interdiscipli- naritu svého výzkumu, využívá nejmodernější technologie, odkazuje na specializované analýzy, publikuje grafy a tabulky, které dávají jeho práci zdání vysoké vědecké úrovně.

Ve své práci Osmanagić neustále akcentuje spolupráci s předními odborníky z různých oblastí výzkumu, at̉ už s archeology, geology, fyziky a dalšími. Do češtiny přeložená monografie (Osmanagić 2018) je doslova plná jmen mnoha tzv. odborníků. Podíváme-li se však na jména podrobněji, zjistíme, že řada tak zvaných odborníků jsou různé osoby vyznávající alternativní „vědecké“ přístupy, nikoliv skuteční vědci. Navíc je známo, že Osmanagić bez dovolení využil jména vědců, kteří s ním nikdy nespolupracovali (Pruitt 2007, 34).

Celá řada „odborníků “ v jeho týmu jsou mladí nedostudovaní lidé, kteří rozhodně nemohou být nazýváni experty svého oboru. ${ }^{38}$ Tito „experti“ se na pracovišti střídají a často dnes nejsou dohledatelní. Momentálně je archeoložkou Osmanagićova týmu Amna Agić. ${ }^{39}$ Tato mladá žena absolvovala v roce 2014 bakalářské 
studium archeologie na sarajevské univerzitě, zapsala se na studium magisterské, které do dnešních dnů nedokončila. ${ }^{40}$

Na internetu je dostupná její nálezová zpráva o výzkumu v tunelech Ravne v letní sezóně 2019 (Agić 2019). Během půl roku trvajícího archeologického výzkumu otevřela Agić spolu se svými amatérskými spolupracovníky několik sond v podzemních tunelech Ravne 3 . V každé sondě byly archeologické situace odkrývány postupně, po jednotlivých vrstvách. Ve svrchních vrstvách se zpravidla nacházely keramické zlomky vrcholně středověkého stáří či hřebíky, níže nálezy raného středověku (z nichž je nejzajímavější Amnou Agić nerozpoznané kování avarsko-byzantské produkce z 8 . století1 ${ }^{11}$ ), a nálezy doby římské. Na dně jedné ze sond se podařilo identifikovat keramiku mladší doby kamenné. Mezi nejzajímavější nálezy z výzkumu patří zajisté několik zkorodovaných měděných (?) mincí, které Agić datuje do doby římské, avšak konstatuje, že jejich bližší určení není vzhledem k pokročilé korozi možné. $\mathrm{V}$ tomto bodě je zarážející především fakt, že na výzkumu, kde se ročně protočí značné sumy peněz, nejsou peníze na odbornou konzervaci nalezených předmětů ani na bližší určení očištěných mincí numismatikem. Je zřetelně cítit, že tyto nálezy nepatří $\mathrm{k}$ tomu, co by Osmanagiće a jeho tým zajímalo.

Až do tohoto bodu se jedná o vcelku běžnou nálezovou zprávu, která sice vykazuje znaky amatérismu, nicméně je zjevné, že výzkum sám o sobě je zajímavý a cenný a mohl by přinést zajímavé informace o využívání podzemních prostor v minulosti. Závěrečná část zprávy se však vymyká standardu běžných nálezových prací. Agić svůj posudek končí konstatováním, že v chodbách byly odkryté na sucho kladené zdi, které byly překryty (není dokumentováno jakým způsobem) stalaktity. Tyto stalaktity byly datovány analýzou radioaktivního uhlíku C14 v Kyjevě a ukázaly stáří 26200 +/-200 a 5900 +/-200 (Agić 2019, 33). Podle Agić jsou tedy tyto na sucho kladené zdi z valounů starší než 26000 let. Amna Agić závěrem soudí, že jsou správné závěry Semira Osmanagiće, který tvrdí, že chodby vystavěly prehistorické civilizace a tyto chodby byly pak využívány dalšími, výrazně mladšími, kulturami.

Tato nálezová práce zapadá do kontextu toho, co se ve Visoku děje a jakým způsobem jsou výsledky prezentovány veřejnosti. Bakalářský titul Amny Agić dává veřejnosti určitý pocit, že na místě pracují skuteční archeologové a nálezová zpráva na laika působí na první pohled vysoce erudovaně. Její vypracování zároveň legitimizuje výkopové práce na lokalitě. Avšak výsledky výzkumu de facto vůbec nejsou brány v potaz. Do pyramidového konceptu se totiž nehodí. Výzkum dokázal, že labyrint částečně přirozeně vzniklých podzemních prostor byl využíván sporadicky v pravěku, v době římské, a především ve vrcholném středověku. ${ }^{42}$ A tak „na objednávku“ byla dopsána část potvrzující Osmanagićovy teorie o výstavbě tunelů před více jak 30000 lety.

Dalším charakteristickým rysem Osmanagićovy rétoriky je kritika oficiální vědy a vědců. Téměř v každém textu se setkáme s tvrzeními, že jsou archeologové omezení, jak se urputně brání novým poznatkům a jak se ze všech sil snaží překazit Osmanagićův projekt. V úvodu Osmanagićovy knihy se mimo jiné dočteme: „Filtrace archeologických informaci elitnimi skupinami nyni konči. Existuje dostatek nezávislých výzkumniku s otevřenou myslí, kteři jsou pripraveni použit moderni družice, termo a geo-radar, geofyziku a nové metody datováni $k$ tomu, aby manipulace reality již dále nepokračovala." (Osmanagić 2018, 8). Semir Osmanagić a jeho tým jsou podle takových zdrojů obětmi elitních vědců, kteří se ho snaží zdiskreditovat. O „intrikách“ ze strany egyptologa Zahí Hawásse píse Osmanagić dokonce na pěti stranách své monografie (Osmanagić 2018, 82-86).

Osmanagić se zkrátka drží hesla „nejlepší obrana je útok“ a nevynechá příležitost, aby 
veřejnosti ukázal, jak jsou profesionální archeologové omezení. Pokud se odborník snaží laické veřejnosti vysvětlit, že pyramidy neexistují, nemá s tímto Osmanagićovým př́istupem vůbec žádnou šanci. A priori je totiž podezříván ze zaujatosti.

Osmanagić má velký vliv na veřejnost doma i v zahraničí. Spolu s bombastickými proklamacemi hraje na citovou stránku. Malá bezvýznamná Bosna má být na co hrdá, je to totiž kolébka světové civilizace a místní obyvatelstvo je jejími potomky: „Malá, neklidná, válkou zpustošená země se stala velmoci na světové archeologické mapě. Až stát finančně podpoři tento projekt, až budou pyramida Slunce, pyramida Měsíce a mohyla ve Vratnici odkryty, až bude celá sît podzemnich tunelư vyčistěná a zabezpečená, budeme mit v Bosně miliony turistů každý rok. Přinesou do Bosny miliony dolari̊, které nastartuji archeologickou turistiku, obchod, rozvoj infrastruktury, hotelnictvi, produkci potravin a dalši odvětví. Ekonomika bude záviset na tomto projektu. Nové generace se budou učit z nových učebnic o pravé historii, na kterou můžeme být pyšni. “ (Osmanagić 2018, 49).

Osmanagić na mnoha místech zdůrazňuje obrovský ekonomický potenciál svého projektu. Téměř v žádném textu nebo rozhovoru nezapomene zmínit, že pyramidy přivádějí do Bosny desetitisíce turistů ročně. Tito turisté pak přinášejí peníze, které zlepšují ekonomickou situaci nejen obyvatel města Visoko, ale potažmo celého státu. Vedle toho je projekt Semira Osmanagiće vnímán jako nástroj ke zlepšení mezinárodního pohledu na Bosnu, zvětšuje to její prestiž a také prestiž všech jejích obyvatel.

V článku z roku 2009 Osmanagić ukazuje, že archeologická turistika může být výrazným zdrojem př́ijmu pro zemi, které disponují významnými archeologickými památkami. V článku Osmanagić poodkrývá tajemství svého úspěchu, když ukazuje, s jakými strategiemi pracuje při turistické propagaci. Vedle faktorů jako je propagace v médiích, zdůrazňování podobností bosenských pyramid s jinými archeologickými lokalitami z celého světa poukazuje též na „kontroverzi jako faktor pritažlivosti“43- to, že lokalitu odmítají odborníci, zároveň přitahuje zájem turistů. Závěrem Osmanagić konstatuje, že „Rozvoj turistické infrastruktury a marketingová propagace jsou nutné kroky $k$ tomu, aby se archeologický turismus stal vưdčím industriálním odvětvím v této části BaH a regionu. "44 (Osmanagić 2009, 26). V kontextu státu, který se stále vzpamatovává z válečných útrap a jehož ekonomická situace není zrovna stabilní, je pak úspěšnost celého projektu pochopitelná.

Semir Osmanagić také zdůrazňuje, že pyramidy jsou památkou, na niž mají být všichni obyvatelé Bosny hrdí, nebot jsou dokladem existence prastaré civilizace na území dnešní Bosny a Hercegoviny. Tvrdí, že dnešní Bosňané jsou potomky nositelů této vyspělé civilizace: „Neni pravda, že Balkán byl osídlen „primitionimi barbarskými Slovany v sedmém století našeho letopočtu“, jak jsme byli západem učeni, ale naopak místni civilizace se šírila právě z Balkánu do Evropy. Dvě třetiny Bosñanů a Hercegovců jsou potomci prunich evropských lidi, kteři prišsli na územi dnešni Bosny, Hercegoviny, Dalmácie a Chorvatských ostrovů. Potomci Slovanu tvoři pouhých deset procent." (Osmanagić 2018, 49). Ruský badatel M. Lomonosov $(2012,83)$ konstatuje, že Osmanagić tvrdí, že Bosňáci jsou vlastně „geneticky a kulturně specifická etnicita, která vytvořila jednu z pronich civilizaci na světěe. "45 a Bosňáci jsou prezentovaní jako historicky daní, právoplatní majitelé celé země (Lomonosov 2012, 83).

Takový přístup k vlastní identitě však není v balkánském prostoru ničím novým. Snaha o doložení kontinuity novodobých národů s kmeny doby železné (a tím zároveň potvrzení nároků na dané území) je známa z Bulharska (Thrákové), Rumunska (Dákové) i Albánie a Kosova (Ilyrové) (Gori 2012). Také v Bosně a Hercegovině se v minulosti již objevily pokusy spojit muslimské obyvatelstvo s dávnými Ilyry 


\section{(1) \\ FONDACIJA ARHEOLOŠKI PARK: BOSANSKA PIRAMIDA SUNCA VISOKO, BOSNA I HERCEGOVINA THE ARCHAEOLOGICAL PARK: BOSNIAN PYRAMID OF THE SUN FOUNDATION VISOKO, BOSNIA AND HERZEGOVINA}

Obr. 3: Logo Nadace Archeologický park: Bosenská pyramida Slunce, zdroj: facebookový profil Semira Osmanagiće, https://www.facebook.com/DrSemirOsmanagich.

Fig. 3: Logo of the Archaeological Park: Bosnian Pyramid of the Sun Foundation, source: http://piramidasunca. $\mathrm{ba} / \mathrm{bs} /$

(více o problematice Lomonosov 2012) a takto zdůraznit odlišnost od okolního slovanského, tedy srbského a chorvatského, obyvatelstva. Semir Osmanagić však jde ještě hlouběji do minulosti, když současné obyvatele Bosny a Hercegoviny spojuje $\mathrm{s}$ př́slušníky civilizace, která podle jeho teorie postavila pyramidy před asi 30000 lety.

Velmi brzy po tom, co Semir Osmanagić oznámil, že v Bosně a Hercegovině jsou nejstarší a nejvyšší pyramidy na světě, získal pyramidový komplex prrízeň bosňáckého obyvatelstva nejen ve městě Visoko, ale i jinde v Bosně. Roli přitom zajisté hrály jednak politicko- ekonomické důvody, ale zároveň i důvody ideologické. Bosňáci lokalitu okamžitě přijali za svou, na rozdíl od chorvatského či srbského obyvatelstva, které se k „objevu“ postavilo vlažně. ${ }^{46} \mathrm{Py}$ ramidy se pro Bosňáky staly poutním místem a prostorem k prožívání vlastní identity (Dzino 2012, 184). Džino poukazuje na symbolický rozměr pyramid, jejich transformaci do jisté podoby sakrálního prostoru: „Prìjetí „bosenských pyramid“ jako symbolu, tedy jejich zformováni do jakéhosi „sakrálniho prostoru“ v bosñácko- bosenských narativech identit umožnilo přežití tohoto pseudoarcheologického projektu i po jeho neúspěchu pokusit se jej začlenit do vědeckého diskurzu. " (Džino 2014,
249). ${ }^{47}$ Co do duchovního významu bývají pyramidy vnímány jako symbolický protiklad chorvatského katolického poutního místa Medjugorje (Pruitt 2007, 37-38).

Pyramidy získaly image bosňáckého národního symbolu. Tehdejší kurátorka Zemského muzea v Sarajevu Ziljka Kujundžić-Vejzagić uvedla: „Vira v pyramidy se stala synonymem vlastenectvi" (citace dle Feder 2014, 266). ${ }^{48}$ Zároveň se objevila agrese vůči těm, kteří se negativně vyjadřovali k existenci pyramid. Odpơrci, kteří se nebáli a objev pyramid prohlásili za lež, byli bosňáckými nacionalisty označeni za nepřátele Bosny, dostávali výhružné dopisy a veřejně byli uráženi. Ziljka Kujundžić-Vejzagić líčí, že jí do muzea volali neznámí lidé a vyhrožovali jí. Hovoří dokonce o tom, že ji jednou jakýsi muž vystrčil z tramvaje se slovy, že je nepř́itel Bosny. ${ }^{49}$ A nebyla jediná, kdo byl za skeptický názor podroben persekuci. Celý spor se dostal i za hranice Bosny a Hercegoviny- profesor z univerzity v Exeteru Anthony Harding obdržel několik dopisů, jejichž pisatelé jej označili na hlupáka a prŕitele Srbu․.$^{50}$ Diskurz vědeckého charakteru se tedy prakticky ihned přenesl do jiné roviny, do roviny nacionalistického diskurzu.

Důležitým znakem celé problematiky je zároveň fakt, že pyramidy jsou oficiálně propagová- 
ny jako nadetnické. Projekt používá symboliku jednotné Bosny a Hercegoviny, v logu nadace je použita symbolika bosenské vlajky (Obr. 3). Semir Osmanagić popírá jakékoliv vazby na politiku či náboženské uskupení, zdůrazňuje, že místo má lidi spojovat a nikoliv rozdělovat: „...(Kritici) vědomě ignoruji skutečnost, že Nadace vždy zdưrazňovala, že tento projekt nemá nic společného s jednotlivými národy ani náboženstvími, ale že patři dávné minulosti, na kterou můžeme být všichni hrdi. Tímto zpuisobem se tento výzkum stává integračním faktorem, něčím, co nás spojuje, ne rozděluje. " 51

Bosenské pyramidy jsou tak názornou ukázkou bosňáckého nacionalismu, který je nenápadný, unifikační a pro vnějšího pozorovatele logický a ospravedlnitelný. Bosňáci se na rozdíl od bosenských Srbů a Chorvatů ztotožňují s ideou jednotného státu, snaží se o co největší centralizaci Bosny a Hercegoviny a rádi využívají státní symboliku. Koncept bosenských pyramid této ideové rovině perfektně odpovídá. Má to být místo pro všechny, má to být kus historie, na nějž mají být hrdí všichni obyvatelé Bosny a Hercegoviny bez rozdílu.

Bosenské pyramidy jsou pseudoarcheologickou lokalitou, jejíž reálná podstata byla vědci z celého světa již mnohokrát vyvrácena. Lokalita však má své nezastupitelné místo v kontextu nestabilního poválečného státu s rozvrácenou ekonomikou a vysokou nezaměstnaností, ve státě, kde politika identit stále hraje velkou roli. Nejde o to, jestli jsou pyramidy skutečné nebo ne. Jde o jejich symbolický a ekonomický význam pro místní obyvatelstvo a politickou reprezentaci. Pyramidy poutají pozornost celého světa, přitahují turisty, jsou symbolem bosňácké identity, a proto projekt není odsouzen k zániku, ačkoliv z vědeckého hlediska je neúspěšný.

Smutnou realitou je zároveň skutečnost, že zatímco projekt bosenského údolí pyramid vzkvétá, skutečná archeologie $\mathrm{v}$ zemi živoří. Zemské muzeum v Sarajevu bylo donedávna za- vřené kvůli problémům s financováním, sbírky trpí v nevhodných podmínkách a kultura je silně podfinancovaná (Džino 2014, 250-251; Mujanović 2014, 15).

\section{Chorvatsko v raném středověku}

Zatímco bosenský prríklad je ukázkou toho, jakým způsobem může být pseudoarcheologická lokalita využita jako určitý „národní symbol“, na něhož mohou být všichni občané hrdí, druhý příklad z Chorvatska naopak upozorňuje na to, jak vědce a jeho práci ovlivňují jeho vlastní postoje a názory. Takový přístup se na rozdíl od prvního př́íladu schovává za pláštíkem vědy a není tak markantní, jako v případě pseudoarcheologie.

V chorvatském prostředí bylo využití, resp. zneužití, minulosti pro nacionalistické účely popsáno vícekrát (např. Gračanin 2010; Budak 2009). Hrvoje Gračanin analyzoval projevy prvního chorvatského prezidenta Franjo Tuđmana, který kladl na význam raného středověku obzvlášt velký důraz. Vyzdvihoval především státoprávní kontinuitu Chorvatska od raného středověku do současnosti a tradice demokracie, v které žili staří Chorvaté. Gračanin poukazuje také na to, že na údajnou státní kontinuitu je odkazováno též v ústavě z roku 1990. Vedle toho politici 90. let zdůrazňovali př́íslušnost Chorvatska $\mathrm{k}$ západoevropskému kulturnímu kruhu a příslušnost Chorvatů ke katolické víře: „Chorvati jsou jednim z nejstaršich národů dnešni Evropy. V době velkého stěhováni národů přišli do těchto oblastí jihovýchodni Evropy, mezi Dunajem a Jadranem, ze sué pravlasti ... Př́řli sem a brzy, již v VII. stoleti prijali víru Krista a ř́mského biskupa za svého vladaře, čimž se stali a zůstali natrvalo nedílnou součásti stavby a obrany západni křestanské civilizace."52 (Gračanin 2010, 93).

Podobně píše i Neven Budak (Budak 2009), který říká, že v 90 . letech došlo k oživení zájmu 
o středověk, raně středověký chorvatský „stát“ byl vnímám jako jediné období chorvatské nezávislosti, a tudíž jakýsi vzor pro nově osamostatněné Chorvatsko. Byla zdůrazňována příslušnost ke katolické církvi a kultura se stala oporou národní hrdosti. Po roce 2000 se rétorika trochu změnila a středověk se začal používat především jako paralela pro evropskou integraci - v roce 2000 proběhla výstava Hrvati i Karolinzi, která měla poukázat na společné kulturní kořeny západní a střední Evropy, a tedy na od raného středověku trvající spojení Chorvatska se západní Evropou (Budak 2009).

Co se týká výkladu klíčového pramene, De administrando imperio Konstantina Porfyrogenneta (Moravcsik 1967), a pohledu na nejstarší chorvatské dějiny, dělí se chorvatští badatelé v zásadě na dvě skupiny. Část badatelů pracuje s hypotézou, že se Chorvaté dostali do Dalmácie již v průběhu sedmého století a ve větší či menší míře přišli do kontaktu se starousedlým romanizovaným obyvatelstvem. Druhá část archeologů pak pracuje s tezí, že Chorvaté osídlili Dalmácii až na konci 8. století. Zároveň ale i tak připouštějí, že hmotná kultura nově příchozích Chorvatů byla ovlivněna romanizovanými starousedlíky. I tito badatelé tak obvykle vnímají kontinuitu v materiálu od sedmého století do vrcholného středověku (více $\mathrm{k}$ problematice a další literatura viz Dvořácková 2020).

Archeolog Vladimir Sokol, bývalý ředitel regionálního muzea v Sesvete, patří k těm osobnostem chorvatské archeologie, které zasahují do společenského diskurzu o „národní“ minulosti. Díky vydání anglické verze jeho monografie o chorvatských pohřebištích v nakladatelství Brill (Sokol 2016; reakce např. Džino 2016; Dvořácková, v tisku) jsou jeho závěry přístupné celosvětovému publiku. Jeho závěry jsou však diskutabilní.

Podle Sokolovy teorie přicházejí Chorvaté do Dalmácie po roce 795 a to $\mathrm{v}$ souladu $\mathrm{s}$ franckou politikou. $\mathrm{V}$ žádném případě nedo- jde ke kontaktu s autochtonní populací, podle Sokola je celý dalmatský prostor neosídlený asi dvě stě let, většinu 7. a celé 8 . století. Při tom argumentuje chybějícími doklady prrítomnosti kultury pražského typu, absencí avarských a merovejských nálezů (Sokol 2006, 109). Své teorii Sokol přizpůsobuje i dataci kamenných obložení hrobových jam. Ta bývají běžně považována za prvek, který nově př́íchozí Slované převzali od autochtonního romanizovaného obyvatelstva. Takové interpretaci se však Sokol důsledně brání a tvrdí, že Chorvaté kamenné konstrukce v žádném případě od starousedlíků převzít nemohli (Sokol 2006, 155-162).

Čteme-li Sokolovu práci, nemůžeme se zbavit otázky, proč se autor tolik brání představě kontaktu mezi Chorvaty a autochtonním obyvatelstvem, ačkoliv je patrná nesmyslnost takového výkladu. Vysvětlení se skrývá v Sokolově osobních postojích vůči nejstarším dějinám chorvatského „státu“ a jejich rezonanci v aktuálním politickém dění. Romanizované starousedlé obyvatelstvo Slované označovali jako „Vlahi“. Tento pojem má ovšem v současném Chorvatsku jiný význam - značí pravoslavné obyvatele, tedy Srby. ${ }^{53}$ Pokud neodlišíme antické „Vlahi“ od těch současných, znamenalo by to, že legitimizujeme nárok současných „Vlahů“ na Chorvatsko, což je pro vlastenecky smýšlejícího Chorvata nepřípustné. ${ }^{54}$

Podobný problém představuje prostorové rozšíření „starochorvatské“ hmotné kultury. V práci Vladimira Sokola nebo archeoložky Maji Petrinec (2009, 3-5) jsou zcela běžně mezi „starochorvatské“ nekropole zařazována i pohřebiště na území dnešní Bosny a Hercegoviny. Sokol považuje ve své práci Bosnu a Hercegovinu za „chorvatský etnický prostor“ (např. Sokol 2006, 174). Bosenské území je také zcela běžně zahrnováno do přehledů chorvatského středověku (např. Bilogrivić 2015).

Stále více archeologů si je přitom vědomo skutečnosti, že na základě hmotné kultury není 
možno odvozovat etnicitu jejích nositelů. Již sám termín „starochorvatský“ (k terminologii více Petrinec 2009, 5) je více než diskutabilní. Pojem je předem interpretační a evokuje pocit, že nebožtík vybavený předměty tzv. „starochorvatské“ kultury byl Chorvatem. Přitom vztah mezi starousedlíky a nově příchozím slovanským etnikem v Dalmácii je problematický a není jednoznačně doložitelné, kdo byl v hrobech 7. až 9. století vlastně pochováván (shrnutí problematiky Dvořácková 2020). Mnohem vhodnější by bylo používat neutrální termín „raně středověký“, protože ten ukazuje na časové zařazení předmětů a nevnucuje žádný etnický výklad.

Pohřebiště v Bosně jsou označována jako „starochorvatská“ na základě polických dějin regionu, kdy chorvatský raně středověký státní útvar měl v době krále Tomislava dosahovat až k řece Drávě a ovládat tak území dnešní Bosny a Hercegoviny (k územnímu vymezení raně středověkého Chorvatska např. Šesták a kol. 2001, 25-26). Už samotné připojení těchto území k jádru země a jejich případné fungování v rámci chorvatského „státu“ je diskutabilní, ale především to rozhodně nic nevypovídá o etnicitě tamních obyvatel. A už vůbec to nemůže být omluvou pro nároky na Bosnu a Hercegovinu jako na "tradični chorvatský etnický prostor". Promítání současných požadavků hluboko do minulosti je možná populární pro širokou veřejnost, odborný diskurz by se ale takovým tezím měl vyhnout. ${ }^{55}$

Začátkem roku 2018 přednesl Vladimir Sokol v knihovně HAZU přednášku, která přitáhla pozornost médií a jejíž výtah následně publikovala celá řada chorvatských novin. ${ }^{56}$ Sokol představil svou konstrukci raně středověkých chorvatských dějin přibližně tímto způsobem: Chorvaté pocházejí z tzv. Bílého Chorvatska, které se nacházelo na území dnešní České republiky. Svědčí o tom toponymie: „Na tom územi Sokol identifikoval toponyma, která pripominaji jména pěti bratrů, kteři podle legendy zapsané v 10. stoleti privedli Chorvaty do nové vlasti: „Hrvat“ je oblast na středni Vltavě kolem mista, které se nazývá Knin, jméno Lobel odkazuje na Labe, Muhlo na Muhilu, dnešni Mühlviertel v Rakousku, Kosjenac na město Kosejovice, Kluk na stejnojmenné město v Čechách, zatímco sestry Tuga a Buga představuji reky Tugar a Buga za Karpaty. "57 Na nesmyslnost takového výkladu snad ani není třeba upozorňovat.

Novinový titulek dále hlásá: „Kdyby Chorvati úspěšne nebojovali s Avary, Europa by dnes vypadala jinak “.58 Média prezentují další události tak, že se Chorvaté do nové vlasti nasídlili koncem 8. století, poté, co je Karel Veliký pověřil zničením avarského kaganátu. Pod vedením Vojnomira dobyli Chorvaté v roce 795 avarské centrum zvané Hring, zabavili Avarům veškeré bohatství, které následně poslali do Francké říše.$^{59}$ Byli to tedy Chorvaté, kterým Karel Veliký svěřil důležitý úkol rozvrátit avarskou řšši a jedině díky Chorvatům Evropa vypadá tak, jak ji známe dnes.

Přednáška Vladimira Sokola tak zapůsobila na čtenáře nejen v Chorvatsku, ale i v Bosně a Hercegovině a v Srbsku. Ještě měsíc po pronesení přednášky a zveřejnění prvních článků probíhaly se Sokolem rozhovory do tisku a jeho představa dějin pronikla kromě seriózního tisku i do bulváru.

Znepokojující je na celé kauze skutečnost, že veřejnosti jsou předkládána „fakta“ postavená na vodě. Jsou vynášena profesionálem, archeologem, a tudíž nikdo nemá důvod pochybovat o jejich pravdivosti. V novinách není prostor pro diskusi a nutno podotknout, že se o ni ani nikdo nesnažil. Historik Neven Budak se k celé kauze vyjádřil jen v tom smyslu, že Sokolova teorie je jen jednou z mnoha. Vyvrátit se ji ale nepokusil, ani nepředložil žádné alternativy, respektive mu $\mathrm{k}$ tomu média nedala prostor. ${ }^{60}$ Fenomén, kdy jsou prostřednictvím médií předkládána nejširšsi veřejnosti diskutabilní závěry z úst archeologa či historika, je bohužel realitou 
nejen v Chorvatsku. ${ }^{61}$ Tato „fakta“ se pak mohou stát základem pro legitimizaci různých nároků a tezí, které by v demokratické společnosti měly být nepř́ípustné.

\section{Závěr}

Předložený článek se věnoval problematice archeologie ve službách národní emancipace. Pokusila jsem se ukázat, že poznání „národní“ minulosti je pro sebeidentifikaci národů a jejich emancipaci klíčové. Moderní národy ze značné části stavějí svou identitu právě na sdílené minulosti a na svých národních mýtech.

Archeologie byla v minulosti hojně využívána pro ospravedlňování různých „národních“ požadavků, především nároků územního charakteru. Pokud chtěl nějaký národ ukázat, že na požadovaném území žije „od pradávna“, sahal obvykle po archeologii a po jejích poznatcích.

Využívání archeologie a jejích poznatků pro nárokování si určitých území není cizí ani zemím bývalé Jugoslávie. Z velkého množství potenciálních „balkánských“ př́́kladů jsem si vybrala dva, a sice pseudoarcheologickou lokalitu „Bosenské údolí pyramid“ a problematiku raně stř̌edověkých pohřebišt na území „chorvatského etnického prostoru“.

Ve své práci jsem srovnala dva odlišné přístupy v zneužívání archeologie při obhajování současných národních požadavků. Nacionalistické nároky nikdy nejsou záležitostí omezené skupiny lidí, ale právě naopak. Takové požadavky nutně vyžadují souhlas a podporu nejširší veřejnosti, „celého“ národa. Proto se nacionalisté musejí obracet k širokým masám, a proto je při prosazování ideologií klíčová komunikace s veřejností. Ve své studii jsem se tedy zaměřila především na tento aspekt - jakým způsobem jsou vědecké či nevědecké poznatky předkládány veřejnosti.
Na jedné straně stojí pseudoarcheologická lokalita, jejíž objevitel komunikuje s bosňáckou částí veřejnosti pomocí jednoduché „národni““ symboliky, která proměnila údajnou „archeologickou“ lokalitu v symbolické duchovní místo bosenského národa. Pyramidy mají být místem, na něž mají být obyvatelé hrdí a víra v pyramidy se stala paralelou vlastenectví. Popularita lokality se šírí masovými sdělovacími prostředky, mimo vlastní akademickou obec. Díky účinné strategii a rétorice má skutečně velký dosah u (především muslimské/bosňácké) veřejnosti.

Naproti tomu druhý př́klad pochází z akademického prostředí. Poukázala jsem na skutečnost, že archeolog je součástí své doby a není schopen se zcela od společenského diskurzu oprostit. Do svých interpretací tak přenáší své životní postoje a názory, at’ už vědomě či nevědomky. Mnozí chorvatští badatelé zcela nekriticky přistupují k tématu etnicity. Za „chorvatský etnický prostor“ považují rozsáhlá území včetně Bosny a Hercegoviny. Raně středověká pohřebiště z celého zkoumaného území pojednávají jako „starochorvatská“, byt’ o etnicitě nebožtíků nevíme vůbec nic. Pohřebiště a jejich hmotná kultura však mají být důkazem toho, že na dotčených územích žili Chorvaté již od okamžiku svého příchodu z daleké pravlasti. Prostřednictvím tuzemských i mezinárodních vědeckých kanálů se pak takto postavené dějinné konstrukty šíŕí mezinárodní vědeckou obcí, která, pokud nezná širší kontext, může tyto teze bez problémů přejímat.

Širrení ideologicky zabarvených vědeckých tezí mezi širší veřejnost probíhá jednak pomocí médií jako je televize, tisk a internet, ale i způsobem sofistikovanějším - prostřednictvím výstav, populárně naučné literatury či přímo školních učebnic. Děti se od útlého věku seznamují s „národni“" historií, respektive s dějinnými konstrukcemi, které společnými silami vytvářjí archeologové, historikové a pomocné vědní obory. Vědci, kteří historické narativy přetvářejí 
a upravují, jsou však sami produkty „svého národa a své doby“. Národní obraz dějin tak nikdy nemůže být objektivní. Nejen kvůli nemožnosti poznat minulost v celé její plastičnosti, ale především právě proto, že my sami nejsme schopni se na ni dívat zcela objektivně.

V okamžiku změny či při pocitu ohrožení mají národy potřebu demonstrovat svoji identitu ještě viditelněji. Obě případové studie se zabývaly prostředím, které kvưli ne tak dávným válečným událostem stále není stabilizované a v němž jsou otázky identit, územních nároků a národnostních menšin stále aktuální. Domnívám se, že pouze stabilizací společenských poměrů v zemích bývalé Jugoslávie je možno dospět k tomu, aby tamní archeologie přestala národním požadavkům sloužit. Svůj text však nemohu zakončit optimisticky - celoevropské trendy, nárůst nacionalismu a volání po vlastní identitě a kultuře však svědčí spís o opaku. Na archeologii bude patrně i nadále vyvíjen tlak, aby sloužila národu a jeho aktuálním požadavkům.

1) Kohnovo členění nacionalismů má však trhliny (např. Rychlik 2020). Podle Kohna západní typ nacionalismu na národní minulosti svou identitu nestaví. To však není tak zcela pravda. Jak ukázal např. M. Dietler (Dietler 1999), i Francie svého času kladla důraz na slavnou galskou minulost a, podobně jako ve stejné době Německo, stavěla velkolepé památníky „národním“ hrdinům z doby protohistorie.

2) „Bratstvo i jedinstvo“.

3) Jedná se o slovansky hovořící muslimské obyvatelstvo, zvané Bosňáci nebo Muslimové (s velkým M).

4) Zdroj ke sčítání lidu z roku 2013: Popis 2013. Popis stanovništva, domačinstava/kućanstava i stanova u BiH (cit. 4. 1. 2021). Dostupné z: https://popis.gov.ba/.

5) V roce 2013 to bylo 24,12 (Zdroj: Popis stanovništva, domačinstava/kućanstava i stanova u BiH. Ekonomske karakteristike. (cit. 4. 1. 2021) Dostupné z: https://www.popis.gov.ba/popis2013/mapa/?lang=bos), v roce 2018 ,jen“ 18,4 (Zdroj: Agencija za statistiku Bosne i Hercegovine (cit. 4. 1. 2021) Dostupné z: http://bhas.gov.ba/Calendar/Category/13).

6) Avakumović, L 2019: BiH druga u svetu po nezaposlenosti mladih - šta je rešenje? Talas 25. 12. 2019 (cit. 4. 1. 2021). Dostupné z: https://talas.rs/2019/12/25/nezaposlenost-mladih-bih/; Einspieler, V. 2016: Bosanci se množično izseljujeji iz domovine, Delo 9. 6. 2016 (cit. 4. 1. 2021). Dostupné z: https://www.delo.si/svet/ evropa/bosanci-se-mnozicno-izseljujejo-iz-domovine.html

7) Zdroj ke sčítání lidu z roku 2011: Popis stanovništva, kućanstava i stanova 2011. Stanovništvo prema državljanstvu, narodnosti, vjeri i materinskom jeziku, Zagreb 2013 (cit. 4. 1. 2021). Dostupné z: https:// www.dzs.hr/Hrv_Eng/publication/2012/SI-1469.pdf.

8) Např. „V Chorvatsku se rozmáhají ustašovské a nacistické symboly, varovala ombudsmanka“, Novinky 21. 11. 2018 (cit. 4. 1. 2021). Dostupné z: https://www.novinky.cz/zahranicni/evropa/clanek/v-chorvatsku-se-rozmahaji-ustasovske-a-nacisticke-symboly-varovala-ombudsmanka-40257523 nebo Vladisavljević, A. 2020: Izveštaj KLJP- a: U Hrvatskoj i dalje prisutni etnička netrpeljivost i govor mržnje, Balkan Transitional Justice 17. 4. 2020 (cit. 4. 1. 2021). Dostupné z: https://balkaninsight.com/2020/04/17/izvestaj-kljp-a-u-hrvatskoj-i-dalje-prisutni-etnicka-netrpeljivost-i-govor-mrznje/?lang=sr.

9) Např. Specijal. Oluja - Dan pobjede, 24Sata (cit. 4. 1. 2021). Dostupné z: https://www.24sata.hr/oluja-dan-pobjede.

10) Úspěch slaví např. hnutí „Domovinski pokret“ nacionalistického zpěváka Miroslava Škora.

11) Více na videu Dr. Sam Osmanagich: Bosnian Pyramids - My story (cit. 4. 1. 2021), Dostupné z: https:// www.youtube.com/watch?v=0sEKQkZOcGc. 
12) Rozhovor viz Intervju sa Zilkom Kujundzic-Vejzagić, 5. 5. 2007 (cit. 4. 1. 2021). Dostupné z: http://piramidasunca.ba/bs/aktuelnosti/item/6200-intervju-sa-zilkom-kujundzic-vejzagic.html.

13) Enver Imamović je jinak známý svým probosňáckým výkladem bosenských dějin a spojováním ilyrských kmenů se současným bosňáckým národem (Hladký 2002, 24; Lomonosov 2012, 70-71).

14) Viz článek Osmanagić: kako su rušene bosanske piramide, 12. 1. 2015 (cit. 4. 1. 2021). Dostupné z: http:// piramidasunca.ba/bs/press/item/9773-osmanagi\%C4\%87-kako-su-ru\%C5\%A1ene-bosanske-piramide.html

15) Např. prohlášení z prosince 2006 (cit. 4. 1. 2021). Dostupné z: https://web.archive.org/ web/20110717134402/http://www.e-a-a.org/statement.pdf.

16) Petice je zmiňovaná na vícero místech, v originálním znění je už nedohledatelná- na http://peticija. white.prohosting.com/ prŕstup v roce 2020 nemožný.

17) $\mathrm{Z}$ webových stránek je možno uvést např. https://irna.fr/ (cit. 4. 1. 2021) nebo http://hotcupofjoe. blogspot.com/search/label/bosnian\%20pyramid (cit. 4. 1. 2021), jiné jsou už dnes nefunkční.

18) V originále: „Finally, it became a useful tool used by the Bosniak political and religious leaders for their own promotion."

19) Od roku 2006 zástupce bosňáckého národa v tř́členném předsednictvu $\mathrm{BiH}$.

20) Woodard, C. 2009: The Mystery of Bosnia's Ancient Pyramids, Smithsonian Magazine, prosinec 2009 (cit. 4. 1. 2021). Dostupné z: https://www.smithsonianmag.com/history/the-mystery-of-bosnias-ancient-pyramids-148990462/.

21) V letech 2002 až 2006 bosňácký člen předsednictva BiH.

22) Celou situaci popisuje přímo dopis: Rose a kol. 2006. O ohroženém skutečném archeologickém dědictví hovoří též otevřený dopis bosenských vědců Vysokému představiteli BaH Christianu Schwarz- Schillingovi (úřad zastával od 1. 2. 2006 do 30. 6. 2007): An open letter from the Bosnian scientific community to Mr. Christian Schwarz-Schilling, High Representative of the international community in Bosnia and Herzegovina, 14. 3. 2007 (cit. 4. 1. 2021). Dostupné z: https://irna.fr/An-open-letter-from-the-Bosnian.html.

23) Více Studijska analiza. Na pažnju članovima Vlade Federacije Bosne i Hercegovine. Za Fondaciju AP BPS: Radna grupa Fondacije, 4. 6. 2007 (cit. 4. 1. 2021). Dostupné z: https://docplayer.org/36948957-Studijska-analiza-na-paznju-clanovima-vlade-federacije-bosne-i-hercegovine-za-fondaciju-ap-bps-radna-grupa-fondacije.html.

24) Např. zde: Ervin Eki Mostić: Hvala ti Semire za ljepše Visoko i BiH, 10. 6.2020 (cit. 4. 1. 2021). Dostupné z: http://piramidasunca.ba/bs/press/item/15738-ervin-eki-mosti\%C4\%87-hvala-ti-semire-za-ljep\%C5\%A1e-visoko-i-bih.html.

25) Četrnaest godina od otkrića bosanskih piramida, piše: dr. Semir Osmanagić, 10. 4.2019 (cit. 4. 1. 2021). Dostupné z: http://piramidasunca.ba/bs/blogovi-3/semir-osmanagic-blog-x/item/14175-\%C4\%8Detrnaest-godina-od-otkri\%C4\%87a-bosanskih-piramida-2.html.

26) Ceník je dostupný na stránkách Nadace: The Archaeological Park: Bosnian Pyramid of the Sun Foundation, Info center Ravne (cit. 4. 1. 2021). Dostupné z: http://visit.piramidasunca.ba/pricelist/.

27) Ravne 2- Programi, 20. 9. 2018 (cit. 4. 1. 2021). Dostupné z: http://piramidasunca.ba/bs/park-ravne-2-programi.html.

28) Đoković: Piramide u Visokom su važne za prosperitet ne samo BiH nego i svijeta, Klix 15. 7. 2020 (cit. 4. 1. 2021). Dostupné z: https://www.klix.ba/sport/tenis/djokovic-piramide-u-visokom-su-vazne-za-prosperitet-ne-samo-bih-nego-i-svijeta/200715087?fbclid=IwAR1q4YGXnHxwdYjT-IroSfYOIVt2e0kbVz2XSyjRet_tE6qw1W19gWwSVn8. 
29) Član Evropskog parlamenta Ivan Sinčić: Bosnaske piramide su svjetska priča, Klix 22. 7. 2020 (cit. 4. 1. 2021). Dostupné z: https://www.klix.ba/lifestyle/clan-evropskog-parlamenta-ivan-sincic-bosanske-piramide-su-svjetska-prica/200722088.

30) Např. na webové stránce Superzajezdy.cz: Bosna a Hercegovina: průzkumná výprava do údolí pyramid ve Visoku (cit. 4. 1. 2021). Dostupné z: https://www.superzajezdy.cz/zeme/bosna-a-hercegovina/poznavaci-zajezdy/bosna-a-hercegovina-pruzkumna-vyprava-do-udoli-pyramid-ve-visoku/ .

31) Největší pyramida světa je v Bosně, tvrdila ČT. Vyvrácený nesmysl, oponují archeologové, Lidovky.cz 13. 11. 2017 (cit. 4. 1. 2021). Dostupné z: https://www.lidovky.cz/domov/ceska-televize-a-bosenske-pyramidy.A171110_171920_ln_domov_rsa.

32) Dobešová, D. 2018: Věděli jste, že Pyramida Slunce v Bosně je vyšší než Cheopsova pyramida?, Novinky 16.3. 2018 (cit. 4. 1. 2021). Dostupné z: https://www.novinky.cz/vase-zpravy/clanek/vedeli-jste-ze-pyramida-slunce-v-bosne-je-vyssi-nez-cheopsova-pyramida-40193266.

33) Jako př́klad mohu uvést např. webové stránky Energie srdce (cit. 4. 1. 2021): https://www.energiesrdce. cz/bosna-a-hercegovina/udoli-pyramid.

34) Webové stránky Nadace: http://piramidasunca.ba/bs/ a její youtube kanál: https://www.youtube. com/user/BosnianPyramidsTV (cit. 4. 1. 2021).

35) Četrnaest godina od otkrića bosanskih piramida, piše: dr. Semir Osmanagić, 10. 4. 2019 (cit. 4. 1. 2021). Dostupné z: http://piramidasunca.ba/bs/blogovi-3/semir-osmanagic-blog-x/item/14175-\%C4\%8Detrnaest-godina-od-otkri\%C4\%87a-bosanskih-piramida-2.html.

36) O léčebných účincích tunelů Ravne se svědectvími návštěvníků hovoří dokument: Ljekovita energija bosanskih pyramida u Visokom (video), RTV Visoko 10. 5. 2020 (cit. 4. 1. 2021). Dostupné z: https:// www.visoko-rtv.ba/ljekovita-energija-bosanskih-piramida-u-visokom-video/.

37) Osmanagić na svém webu uvádí, že je členem Ruské akademie věd, což dokládá fotografí́ průkazu a potvrzení o přijetí (cit. 4. 1. 2021). Dostupné z: http://semirosmanagic.com/images/memberb.jpg.

38) O problematice stěží vystudovaných osob v Osmanagićově týmu pojednává článek An outstanding team of experts, Le site d'Irna 31. 1. 2011 (cit. 4. 1. 2021). Dostupné z: https://irna.fr/An-outstanding-team-of-experts.html.

39) Amna Agić nova arheologinja na lokalitetu bosanskih pyramida, Novum 5. 2. 2019 (cit. 4. 1. 2021). Dostupné z: https://novum.ba/vijest.php?id=29759.

40) Dle písemného sdělení vedoucího katedry archeologie univerzity v Sarajevu prof. Adnana Kaljanace.

41) Za bližší určení předmětu děkuji Nadě Profantové.

42) Podzemní chodby jsou s největší pravděpodobností pozůstatky středověké důlní činnosti. Uvažuje se také o jejich rozšíření partyzány během druhé světové války, např. Lomonosov 2012.

43) V originále „Kontraverza kao faktor privlačnosti“ (Osmanagić 2009, 24).

44) V originále „Razvoj turističke infrastrukture i marketinška promocija su neophodni koraci kako bi arheološki turizam postao vodeća industrijska grana u ovom dijelu BiH i regiona. "

45) V originále ,... the Bosniaks as a genetically and culturally specific ethnicity, who had created one of the first civilizations in the world" (Lomonosov 2012, 83).

46) Danijel Džino poukázal na rozdíl ve vnímání lokality politickými špičkami. Zatímco politické elity bosňácké části populace pyramidy navštěvovaly opakovaně, političtí představitelé bosenských Srbů ani Chorvatů o projekt neprojevili žádný zájem (Dzino 2012, 184). Rozdí je též mezi Bosňáky a Srby či Chorvaty v tom, jestli na pyramidy věří nebo nevěří. Podle průzkumu na středních školách v Mostaru věří tomu, že pyramidy existují 88 \% studentů bosňáckého původu, zatímco chorvatští žáci věrí pyramidám jen z 31 \% (Džino 2014, 49). 
47) V originále „Dakle, prihvaćanje „bosanskih piramida“ kao simbola, odnosno njihovo uobličavanje u svojevrstan „sakralni prostor“ u bošnjačko-bosanskim identitetskim narativima omogućilo je ovom pseudoarheološkom projektu preživljavanje $i$ nakon njegova neuspjeha u nastojanjima da se ugradi u znanstveni diskurs “.

48) V originále „To believe in the pyramids has become synonymous with patriotism” (Feder 2014, 266).

49) Woodard, C. 2009: The Mystery of Bosnia's Ancient Pyramids, Smithsonian Magazine, prosinec 2009 (cit. 4. 1. 2021). Dostupné z: https://www.smithsonianmag.com/history/the-mystery-of-bosnias-ancient-pyramids-148990462/.

50) Tamtéž; Na můj přímý dotaz mi prof. Harding e-mailem odpověděl, že skutečně v letech 2007 a 2008 obdržel celou řadu výhružných e-mailů z řad bosňácké veřejnosti.

51) V originále „... (Kritici) Svjesno zanemaruju činjenicu da je Fondacija uvijek isticala da ovaj projekat nema veze sa pojedinim nacijama i religijama već da pripada dalekoj prošlosti na koju svi možemo biti ponosni. Na taj način ovo istraživanje postaje integrativni faktor, ono što nas spaja, a ne razdvaja “ Citace z článku: Kako su rušene bosanske piramide, 12. 1. 2015 (cit. 4. 1. 2021). Dostupné z:.http://piramidasunca.ba/bs/press/ item/9773-osmanagi\%C4\%87-kako-su-ru\%C5\%A1ene-bosanske-piramide.html.

52) V originále „Hrvati su jedan od najstarijih naroda današnje Europe. Oni su, u doba velike seobe naroda, u ova područja jugoistočne Europe, izmedu Dunava i Jadrana, došli iz svoje pradomovine ... Došavši ovamo, oni su ubrzo, još u VII. stoljeću prihvatili Kristovu vjeru i rimskoga biskupa kao njegova namjesnika, postavši $i$ ostavši za trajna vremena sastavnim dijelom izgradnje i obrane zapadne kršćanske uljudbe "(Tuđmanův proslov při př́iležitosti návštěvy Chorvatska papežem Janem Pavlem II. V roce 1994, citováno podle Gračanin 2010, 93).

53) Heslo Vlasi, enciklopedija.hr, Leksikografski závod Miroslav Krleža, (cit. 4. 1. 2021) „U Hrvatskoj i u dijelovima BiH Vlah znači pravoslavac, odn. najčěśée Srbin“, Dostupné z: https://www.enciklopedija.hr/natuknica.aspx?id=65061.

54) Za tuto myšlenku děkuji prof. Andreji Pleterskému z Inštitutu za arheologijo ZRC SAZU v Lublani.

55) Nicméně k promítání současných územních nároků hluboko do minulosti docházelo a stále dochází. Dějiny Bosny a Hercegoviny byly a jsou integrální součástí chorvatských i srbských historických narativů, jak ukázal např. Hladký 2002.

56) Např. zde: Arheolog Vladimir Sokol: „Hrvati so doselili krajem osmog stoljeća, a Češka nam je pradomovina, Narod.hr 16. 2. 2018 (cit. 4. 1. 2021). Dostupné z: https://narod.hr/hrvatska/arheolog-vladimir-sokol-hrvati-doselili-krajem-osmog-stoljeca-a-ceska-nam-pradomovina.

57) V originále „Na tom je području Sokol identificirao toponime koji podsjećaju na imena petero braće koji su prema legendi zapisanoj u desetom stoljeću doveli Hrvate u novu domovinu: Hrvat je oblast uz srednju Vltavu oko mjesta koje se zove Knin, ime Lobel se odnosi na Labu, Muhlo se odnosi na Muhilu, današnji Mühlviertel u Austriji, Kosjenac na grad Kosejovice, a Kluk na istoimeni grad u Češkoj, dok sestre Tuga i Buga predstavljaju rijeke Tugar i Bug iza Karpata. “ Zdroj citace: článek Arheolog o podrijetlu Hrvata: Ovdje nismo stigli u 7. stoljeću, a Iran nam nije pradomovina, Index.hr 16. 2. 2018 (cit. 4. 1. 2021). Dostuúpné z: https:// www.index.hr/magazin/clanak/arheolog-o-podrijetlu-hrvata-ovdje-nismo-stigli-u-7-stoljecu-a-iran-nam-nije-pradomovina/1026499.aspx.

58) V originále „Da Hrvati s Avarima nisu uspješno ratovali, Europa bi danas drugačije izgledala“. Zdroj citace: článek Arheolog Vladimir Sokol: „Hrvati so doselili krajem osmog stoljeća, a Češka nam je pradomovina, Narod.hr 16. 2. 2018 (cit. 4. 1. 2021). Dostupné z: https://narod.hr/hrvatska/arheolog-vladimir-sokol-hrvati-doselili-krajem-osmog-stoljeca-a-ceska-nam-pradomovina.

59) Např. článek Predavanje Vladimira Sokola. Ugledni arheolog nakon novih istraživanja odkrio odakle su i kada doista došli Hrvati. Nisu stigli iz Irana, nisu tu ni od stoleća sedmog... Jutarnji.hr 16. 2. 2018 (cit. 4. 1. 2021). Dostupné z: https://www.jutarnji.hr/vijesti/hrvatska/ugledni-arheolog-nakon-novih-istrazi- 
vanja-otkrio-odakle-su-i-kada-doista-dosli-hrvati-nisu-stigli-iz-irana-nisu-tu-ni-od-stoljeca-sedmog-7040659. Název článku naráží na Chorvatům notoricky známou píseň zpěváka Dražena Žanka Od stoljeća sedmog z roku 1992.

60) Viz článek Rašović, R. 2018: Hrvati stigli u 8. st. iz Češke? Budak: O najranijoj povijesti Hrvata raspravlja se već 150 godina, Večernji 17. 2. 2018 (cit. 4. 1. 2021). Dostupné z: https://www.vecernji.hr/vijesti/ hrvati-stigli-u-8-st-iz-ceske-budak-o-najranijoj-povijesti-hrvata-raspravlja-se-vec-150-godina-1226971.

61) U nás stačí připomenout projevy spisovatele a historika Vlastimila Vondrušky ohledně současné společensko-politické situace a jeho přirovnávání aktuální situace k minulosti; pro laického konzumenta jeho projevy působí důvěryhodně, protože ,jako historik to musí vědět“.

\section{Bibliografie}

Kaljanac, Adnan: Písemná e-mailová komunikace v červnu 2020

Harding, Anthony: Písemná e-mailová komunikace v červenci 2020

Agić, A. 2019: Izvještaj o arheološkim istaživanjima u tunelima Ravne 3, Visoko, nepublikovaná nálezová zpráva. (cit. 4. 1. 2021). Dostupné z: http:// piramidasunca.ba/images/2019/11/izvjestaj-rav3-2019.pdf?29112019.

Arnold, B. 1990: The Past as Propaganda: Totalitarian Archaeology in Nazi Germany, Antiquity 64, 549-569.

Biermann, F. 2009: Kommentar zum Aufsatz von Florin Curta: Utváření Slovanů (se zvláštním zřetelem k Čechám a Moravě) - The Making of the Slavs (with a special emphasis on Bohemia and Moravia), Archeologické rozhledy 60 - Komentár k článku Florina Curty: Utváření Slovanů (se zvláštním zřetelem k Čechám a Moravě), Archeologické rozhledy 60, Archeologické rozhledy 61, 337-349.

Bilogrivić, G. 2015: Bosna i Hum/ Hercegovina. In: Nikolić Jakus, Z. (ed.) 2015: Nova zraka u europskom svjetlu. Hrvatske zemlje u ranom srednjem vijeku (oko 550 - oko 1150). Zagreb.

Bilogrivic, G. 2016: Etnički identiteti u ranosrednjovjekovnoj Hrvatskoj - materijalni i pisani izvori. Doktorski rad. Filozofski fakultet, Sveučilište u Zagrebu. Zagreb. (cit. 4. 1. 2021). Dostupné z: http://darhiv.ffzg.unizg.hr/id/eprint/6293/.

Brather, S. 2000: Ethnische Identitäten als Konstrukte der frühgeschichtlichen Archäologie, Germania 78, 139-177.
Brather, S. 2001: Slawenbilder „Slawische Altertumskunde" im 19. und 20. Jahrhundert - Obrazy Slovanů. „Slovanské starožitnosti“ v 19. a 20. století, Archeologické rozhledy 53, 717-751.

Budak, N. 2009: Using the Middle Ages in Modern-day Croatia. In: Bak, J. - Jarnut, J. - Monnet, P. - Schneidemüller, B. (eds.): Gebrauch und Missbrauch des Mittelalters, 19.-21. Jahrhundert Uses and Abuses of the Middle Ages: 19th-21st Century Usages et Mesusages du Moyen Age du XIXe au XXIe siecle. Mittelalter Studien 17. München, 241-262.

Budilová, L. J. 2012: Náboženství, sociální třída a rozvoj nacionalismu na Balkáně. In: Balkán a nacionalismus. Labyrintem nacionální ideologie. Porta Balkanica, Brno, 17-38.

Curta, F. 2008: Utváření Slovanů (se zvláštním zřetelem k Čechám a Moravě) - The making of the Slavs (with a special emphasis on Bohemia and Moravia), Archeologické rozhledy 60, s. 643-694.

Dietler, M. 1999: „Naši předkové Galové“: archeologie, etnický nacionalismus a manipulace s keltskou identitou v moderní Evropě, Archeologické rozhledy 51, 537-556.

Dvoŕáčková, S. 2020: Archeologie ve službách národní emancipace. Příklady z Chorvatska a Bosny a Hercegoviny. Nepublikovaná bakalářská práce KJBS FF UK Praha.

Dvoŕáčková, v tisku: recenze Vladimir Sokol: Medieval Jewelry and Burial Assemblages in Croatia. A Study of Graves and Grave Goods ca. 800 to ca. 1450 .

Dzino, D. 2012: Commentary: Archaeology and the (De)Construction of Bosnian Identity. In: Ríagáin, R. O. - Popa, C. N. (eds.): Archaeology and the (De)Construction of National and Supra-National 
Polities. Archaeological Review from Cambridge Volume 27.2. Cambridge, 179-188.

Džino, D. 2016: Prikaz knjige: Vladimir Sokol, Medieval Jewelry and Burial Assemblages in Croatia. A Study of Graves and Grave Goods ca. 800 to ca. 1450, Starohrvatska prosvjeta 43, 317-318.

Džino, D. 2014: „Bosanske piramide“: Pseudoarheologija i konstrukcija društvene zbilje u daytonskoj Bosni i Hercegovini, Status: Magazin za političku kulturu i društvena pitanja 17, 245-252.

Eriksen, T. H. 2012: Etnicita a nacionalismus. Antropologické perspektivy. Praha.

Fagan, G. G. 2006: Diagnosing pseudoarchaeology. In: Fagan, G. G. (ed.): Archaeological fantasies: How pseudoarchaeology misrepresents the past and misleads the public. London, 23-46.

Feder, K. L. 2014: Frauds, myths, and mysteries: science and pseudoscience in archaeology. New York.

Gellner, A. 1993: Národy a nacionalismus. Praha.

Gori, M. 2012: Who are the Illyrians? The Use and Abuse of Archaeology in the Construction of National and Trans-National Identities in the Southwestern Balkans. In: Ríagáin, R. O. - Popa, C. N. (eds.): Archaeology and the (De)Construction of National and Supra-National Polities. Archaeological Review from Cambridge Volume 27.2. Cambridge, 71-84.

Gračanin, H. 2010: Hrvatsko rano srednjovjekovlje u službi politike u počecima neovisne Hrvatske, Kroatologia 1, 89-101.

Hammer, O. - Swartz, K. 2020: Field Notes. The Bosnian Pyramid Phenomenon, Nova Religio: The Journal of Alternative and Emergent Religions, Volume 23, Issue 4, 94-110. (cit. 4. 1. 2021). Dostupné z: https://online.ucpress.edu/ $\mathrm{nr} /$ article/23/4/94/107337/The-Bosnian-Pyramid-Phenomenon?searchresult $=1$.

Harding, A. 2007: The great Bosnian pyramid scheme. British Archaeology 92, 40-44.

Hladký, L. 2002: Dějiny Bosny a Hercegoviny - předmět sporu mezi srbskou, chorvatskou a muslimskou historiografií. In: Studia Balcanica Bohemo-Slovaca V, Spisy Masarykovy univerzity v Brně, Filozofická fakulta, 20-26.

Hroch, M. 2003: Úvodem k čítance textů o nacionalismu. In: Hroch, M. (ed.): Pohledy na národ a nacionalismus. Čítanka textů. Praha, 9-23.
Hroch, M. 2009: Národy nejsou dílem náhody. Př́ičiny a předpoklady utváření moderních evropských národů. Praha.

Kampschror, B. 2006: Pyramid Scheme, Archaeology Magazine 59/4, (cit. 4. 1. 2021). Dostupné z: https://archive.archaeology.org/0607/abstracts/ bosnia.html.

Kuna, M. - Starcová, M. - Mařiková-Kubková, J. a kol. 2019: Sto let v archeologii. Objevy, nálezy a expedice Archeologického ústavu v Praze 1919-2019. Praha.

Květina, P. 2010: Archeologie smyšlené identity - The archaeology of fabricated identity, Archeologické rozhledy $62,629-660$.

Lomonosov, M. 2012: Illyrianism Bosnian Style: Balkan antiquity in contemporary national mythology and identity construction among the Bosniaks, The South Slav Journal 31/3-4, 61-83.

Moravcsik, G. (ed.) 1967: Constantine Porphyrogenitus. De administrando imperio. Washington.

Mujanović, M. 2014: Nekonečný volný pád - Kulturní politika v Bosně: Žít a vzdorovat, Tvar 13, 14-15.

Normark, J. 2012: „Osmanagić and Majanism“, Arqueologia Publica Journal 2, 35-37.

Osmanagic, S. 2009: Bosanska dolina piramida - turistički proizvod globalnog značaja, Univerzitetska kronika, Stručni časopis Univerziteta u Travniku 2/2, 20-26. (cit. 4. 1. 2021). Dostupné z: http:// fmpe.edu.ba/images/pdf/CASOPIS_TRAVNIK No2_a.pdf.

Osmanagić, S. 2018: Bosenská pyramida Slunce. eBook. Sarajevo - Praha. (cit. 4. 1. 2021). Dostupné z: https://danielabosna.files.wordpress. com/2016/10/ebook_bosenska-pyramida-slunce_semir-osmanagic.pdf.

Petrinec, M. 2009: Gräberfelder aus dem 8. bis 11 . Jahrhundert im Gebiet des frühmittelalterichen Kroatischen Staates. Split.

Pleterski, A. 2009: The inventing of Slavs or inventive Slavs? O ideovém světě a způsobu bydlení starých Slovanů - The Inventing of Slavs or Inventive Slavs? About the Ideological and Dwelling System of the Old Slavs, Archeologické rozhledy 61, 331-336.

Pleterski, A. 2013: Slované a Vlaši u bran Itálie v souvislosti s etnogenezí Slovanů, Archeologické rozhledy $65,618-641$. 
Pohl, W. 2010: Archaeology of identity: introduction. In: Pohl, W. - Mehofer, M. (eds.) 2010: Archaeology of identity - Archäologie der Identität. Forschungen zur Geschichte des Mittelalters, Band 17. Wien, 9-23.

Profantová, N. 2009: Kultura s keramikou pražského typu a problém šíření slavinity do střední Evropy. K článku Florina Curty - The Prague-type pottery culture and the problem of diffusion of Slavinity into central Europe. On the article by Florin Curta, Archeologické rozhledy 61, 303-330.

Prtina, S. 2005: „Východní“ vs. „západní“ koncept nacionalismu: Případ Bosny a Hercegoviny, Politologický časopis 1/2005, 27-39.

Pruitt, T. C. 2007: Addressing invented heritage: the case of the Bosnian pyramids. Nepubl. diplomová práce University of Cambridge. (cit. 4. 1. 2021). Dostupné z: http://www.irna.fr/IMG/pdf/Addressing.pdf.

Pruitt, T. C. 2012: Pyramids, Performance and Pseudoscience in Visoko, Bosnia, Arqueologia Publica Journal 2, 26-34.

Rose, M. 2006: More on Bosnian „Pyramids“, Archaeology Magazine, (cit. 4. 1. 2021). Dostupné z:_http://www.archaeology.org/online/features/ osmanagic/update.html.

Rose, M. a kol. 2006: „Bosnian pyramids“: a pseudoarchaeological myth and a threat to the existing cultural and historical heritage of Bosnia- Herzegovina. Dopis z 12. 6. 2006 adresovaný generálnímu řediteli organizace UNESCO Koichiro Matsuurovi. (cit. 4. 1. 2021). Dostupné z: https://archive. archaeology.org/online/features/osmanagic/ UNESCO.pdf.

Rychlik, J. 2016: Chorvatsko. In: Pelikán, J. a kol. 2016: Státy západního Balkánu v uplynulém čtvrtstoletí a perspektivy jejich vývoje. Praha, 231-280.

Rychlik, J. 2020: K problému formování národní identity a vzniku národních států na Balkáně. (cit. 4. 1. 2021). Dostupné z: https://balkansbg.eu/ en/content/balkan-identities/435-balkan-identities-32.html.

Sokol, V. 2006: Hrvatska srednjovjekovna arheološka baština od Jadrana do Save. Zagreb.

Sokol, V. 2016: Medieval Jewelry and Burial Assemblages in Croatia. A Study of Graves and Grave Goods ca. 800 to ca. 1450. Leiden - Boston.
Šesták, M. a kol. 2001: Dějiny jihoslovanských zemí. Praha.

Šistek, F. 2017: Diskurzy o př́ičinách násilí na moderním Balkáně. In: Loewenstein, B. - Hlavačka, M. - Šístek, F. (eds.): Násilí: jiná moderna (Violence: Another Modernity), Praha, 89-114.

Štefan, I. 2011: Doslov: Etnicita v raném středověku aneb pátrání po původu kabátu, který už se nenosí. In: Urbańczyk, P. (ed.): „Neslované“ o počátcích Slovanů. Praha, 103-109.

Štěpánek, V. 2012: Několik pohledů na nacionalismus - jeden z faktorů rozpadu Jugoslávie. In: Balkán a nacionalismus. Labyrintem nacionální ideologie. Porta Balkanica, Brno, 39-55.

Thiessová, A. M. 2007: Vytváření národních identit v Evropě 18. až 20. století. Brno.

Turek, J. 2019: Propaganda a politické angažmá středoevropské archeologie - Propaganda and political engagement of Central European Archaeology. In: Mellnerová-Šuteková, J. - Bača, M. - Pavúk, P. (eds): SALVE EDVARDE! A TOAST TO THE JUBILEE OF PROFESSOR E. KREKOVIČ, Studia Archeologica et Medievalia Tomus XII, Bratislava, 203-221.

Vrabac, S. a kol. 2006: Izvještaj o geološkim iztraživanjima Visočice kod Visokog. (cit. 4. 1. 2021). Dostupné z: https://irna.fr/IMG/pdf/Output.pdf.

Žarković, J. 2014: Bosna a Hercegovina - střet identit: státní, národní, etnické, jazykové, náboženské, kulturní. In: Bittnerová, D. - Moravcová, M. (eds.): Etnické komunity. Lidé Bosny a Hercegoviny. Praha, 105-115.

Žila, O. 2013: Sebeidentifikace, statistika a její interpretace - etnicky smíšená manželství, Jugoslávci a muslimská otázka v Bosně a Hercegovině v kontextu národnostní politiky socialistické Jugoslávie, Historický časopis 61/3, 513-532.

Žila, O. 2016: Bosna a Hercegovina. In: Pelikán, J. a kol. 2016: Státy západního Balkánu v uplynulém čtvrtstoletí a perspektivy jejich vývoje. Praha, 73-135.

Žíla, O. 2018: Poločas rozpadu? Dvojí štěpení daytonské Bosny a Hercegoviny, Porta Balkanica 10, č. 1-2, 5-20.

Žila, O. 2019: Mezi bratrstvím a jednotou a nacionalismem: Národní klíč v socialistické a daytonské Bosně a Hercegovině, Slovanský přehled 105/1, 65-85. 


\section{Archaeology in the service of national emancipation - two examples from Bosnia and Herzegovina and Croatia}

The presented study is dealing with the problem of archaeology in the service of national emancipation. The awareness of "national" history is of key importance for the self-identification of nations and their emancipation. Modern nations base their identity for the most part on the shared history and on their own national myths.

In the past, archaeology has often been used to justify various "national" requirements, above all territorial claims. When a nation wanted to show that they live on a claimed territory "from time immemorial", they usually argued with archaeological knowledge. Archaeology played an important role in justification of territorial claims of Nazi Germany (e.g. Arnold 1990) and the extensive archaeological excavations in socialist countries after the World War II were nothing less than an effort to show that the Slavs occupied our territory earlier than the Germans (Turek 2019). The use of archaeological knowledge to justify territorial claims is also known from the countries of former Yugoslavia (Gori 2012). The study pays attention to two other examples - the pseudo-archaeological (Fagan 2006) site of the "Bosnian valley of pyramids" and the problem of early medieval cemeteries in the territory of the "Croatian ethnic space".

However, nationalistic claims are never a matter of a limited group of people, quite the opposite. Such claims inevitably require consent and support from the general public, the "whole" nation. Nationalists must therefore appeal to wide masses and the public relations are of key importance for the enforcement of ideologies. For this reason, the article is mainly focused on the aspect of how the scientific or non-scientific knowledge is presented to the public.

On the one hand is a pseudo-archaeological site, whose discoverer Semir Osmanagić (Fig. 2) (Osmanagic 2018) communicates with the Bosniak people with the help of a simple "national" symbolism, which changed an ordinary "archaeological" site into a symbolical spiritual place of the Bosniak/Bosnian nation. The pyramids (Fig. 1) are meant to be a place that the inhabitants should be proud of and the faith in pyramids became a parallel to patriotism. The po- pularity of the site spreads through mass media, outside the academic community. An effective strategy and rhetoric make it indeed widely known.

The second example, on the other hand, comes from the world of science. An archaeologist is integral to his time and so he is not able to completely disregard the social discourse. He thus transfers, whether intentionally or not, his own life attitudes and opinions to his interpretations. Some researchers totally uncritically approach the topic of ethnicity. They place the "Croatian ethnic space" (Sokol 2006) to vast territories including Bosnia and Herzegovina. They regard the early medieval cemeteries from the whole investigated area as "Old Croatian", although we know absolutely nothing about the ethnicity of buried individuals. However, the cemeteries and their material culture are meant to be a proof that the Croats lived in the given territories already since the moment of their arrival from a distant original homeland.

The historical constructs and national narratives created by archaeologists then spread primarily through scientific literature, by publication of individual articles or monographs.

The spread of ideologically tinged theories among the general public proceeds through media like television, press and internet, but also in a more sophisticated way - by means of exhibitions, popularisation literature or directly by schoolbooks. Children learn from their early age about "national" history or about historical constructs, which are created by a joint cooperation of archaeologists, historians and auxiliary disciplines. However, scientists who transform and modify historical narratives are themselves a product of "their nation and their time". The national interpretation of history thus never can be objective. Not only due to impossibility to know the past in its full plasticity, but mainly due to the fact that we ourselves are not able to regard it objectively. At the moment of change or in danger, nations feel the urge to demonstrate their identity even more apparently. The two case studies are dealing with a milieu which is not yet stabilised and in which the questions of identities, territorial claims and national minorities are still vividly discussed. 


\section{Soňa Dvořáčková}

- Ústav archeologie a muzeologie,

Filozofická fakulta, Masarykova univerzita,

A. Nováka 1, 60200 Brno, Česká republika

440240@mail.muni.cz 
